\title{
Pyrrolodiazines. 4. Structure and Chemistry of 3,4-Dihydropyrrolo[1,2-a]pyrazine
}

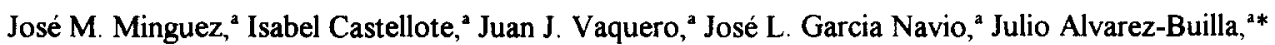 \\ Obis Castañob \\ 'Departamento de Quimica Orgánica and 'Departamento de Química Física, Universidad de Alcalá, 28871-Alcalá de Henares, \\ Madrid, Spain \\ José L. Andrés \\ Institut de Quimica Computational, Universitat de Girona, C/Albareda, 3-5, 17071-Girona. Spain.
}

\begin{abstract}
Abtract: The structure of 3,4-dihydropyrrolo[1,2-a]pyrazine and its N-protonated form is studied by ab initio calculations. Examples of the reactivity of this poorly studied system are presented in which it is shown that the imino moiety does not react with dienes but does undergo inter- and intramolecular 1,3-dipolar cycloadditions by reaction of azomethine ylides of this bicyclic system with suitable dipolarophiles.

() 1997 Elsevier Science Ltd.
\end{abstract}

\section{INTRODUCTION}

The 3,4-dihydropyrrolo[1,2-a]pyrazine 1 is the only known dihydroderivative of the pyrrolodiazine system ${ }^{1}$ and its synthesis is reported in poor overall yield. ${ }^{2}$ In the first report in this series we demonstrated that 1 could be prepared in an acceptable yield and transformed into some 2,2-biazole derivatives 2 and heterobetaines $3^{3}$ despite its considerable instability.

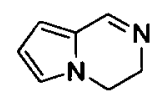

1<smiles>[R]c1c([R])c2n(c1C(=O)c1ccccc1)CCn1cccc1-2</smiles>

2<smiles>O=C(c1ccccc1)c1c([Si-])n(-c2ccccc2)c2[n+]1CCn1cccc1-2</smiles>

3

\section{Scheme 1}

An interesting feature of this bicyclic heterocycle is the presumably high electronic density around the imine resulting from the $\pi$-excessive nature of the pyrrole moiety and the planarity imposed by the ethylene bridge. This characteristic spurred us to study its structure by ab initio calculations and we now report the results of this study along with further examples of the reactivity of this system, especially of some of its azomethine ylides in inter- and intramolecular 1,3-dipolar cycloadditions which in one case presents an interesting change in the regioselectivity of the reaction. 


\section{COMPUTATIONAL METHODS}

The electronic structure of the 3,4-dihydropyrrolo[1,2-a]pyrazine 1 and its protonated form 1a was studied using $a b$ initio MO techniques. All the geometries were fully optimized at the closed shell Restricted Hartree-Fock (RHF) level of theory and using Möller-Plesset perturbation theory of second order (MP2). In both cases, the 6$3 \mathrm{IG}^{*}$ basis set ${ }^{4}$ was used to optimize the geometries. Charges were obtained from a Mulliken population analysis of the wave function. For the thermodynamic analysis the Hartree-Fock energy was corrected using the MP2 perturbation theory with frozen core MP2(FC)/6-31(d). Harmonic vibrational frequencies were computed at the $\mathrm{RHF} / 6-3 \lg (\mathrm{d})$ level (without exception all values were positive) and were used to determine the zero-point energy (ZPE) values, thermal corrections, and entropies for 1 and 1a. ZPE were corrected with the factor 0.893 . All the calculations were performed using the Gaussian 94 sets of programs. ${ }^{5}$

\section{RESULTS AND DISCUSSION}

Geometries and charges on heavy atoms of 1 and the N-protonated form 1 a (a model for either protonated or $\mathrm{N}$-alkylated derivatives) are given in Figure 1 and the calculated geometrical parameters obtained are listed in Tables 1 and 2. The nitrogen atoms show negative charges, with N5 showing the highest electron density. Regarding the carbon atoms, $\mathrm{C} 7$ and $\mathrm{C} 8$ show comparatively high electronic densities, both in 1 and in 1a, with C6 being affected by the conjugation with the imine group. Conversely, the imino $\mathrm{Cl}$ carbon shows comparatively lower electronic density in the salt structure 1a. A similar effect would be expected in the quaternary salts. The fully optimized geometries show $\mathrm{C}_{1}$ symmetries which are slightly non-planar, with the $\mathrm{N} 2$, $\mathrm{C}_{3}$ and $\mathrm{C}_{4}$ atoms being out of the plane of the pyrrole ring $\left(-5.3^{\circ},-14.0^{\circ}\right.$ and $+8.1^{\circ}$ respectively). In $1 \mathrm{a}$ these values for the parent atoms are $-3.7^{\circ},-12.2^{\circ}$ and $+10.7^{\circ}$ respectively. A value of $234.68 \mathrm{Kcal}_{\mathrm{mol}}{ }^{-1}$ for the gas-phase basicity (GB) and $227.03 \mathrm{Kcal}^{\mathrm{mol}}{ }^{-1}$ for the proton affinity (PA) of the 3,4-dihydropyrrolo[1,2-a]pyrazine (1) were obtained. ${ }^{6}$ In Fig 2 the HOMO and LUMO orbitals and their corresponding energies are presented. Only atomic orbitals with coefficients larger than 0.1 are depicted.

Although the feasibility of forming reactive azomethine ylides from quaternized salts of 1 has already been verified, the low stability of 1 at room temperature coupled with to the hygroscopic character of its salts was a serious limitation in our initial report, which focussed mainly on the reactivity of the 2-phenacyl-3,4dihydropyrrolo[1,2-a]pyrazinium bromide, the most stable salt obtained. ${ }^{3}$ We recently found that distillation of 1 under reduced pressure, followed by immediate quaternization allowed us to isolate for the first time the 2-ethoxycarbonylmethyl salt $\mathbf{4 a}$ and the trimethylsilylmethyl salt $\mathbf{4 b}$ with a higher degree of purity. (Scheme 1). However all our attempts to isolate the 2 -amino salt $4 \mathrm{c}$ by amination of 1 with $\mathrm{O}$-(mesitylenesulfonyl)-hydroxylamine (MSH) ${ }^{7}$ were fruitless, with extensive decomposition of the amination reagent being observed.

Although our previous attempts to trap the non-stabilized ylide generated from $4 \mathrm{~b}$ by fluoride-induced desilylation resulted in complex reaction mixtures with no evidence for the formation of the cycloadducts, ${ }^{3}$ our 

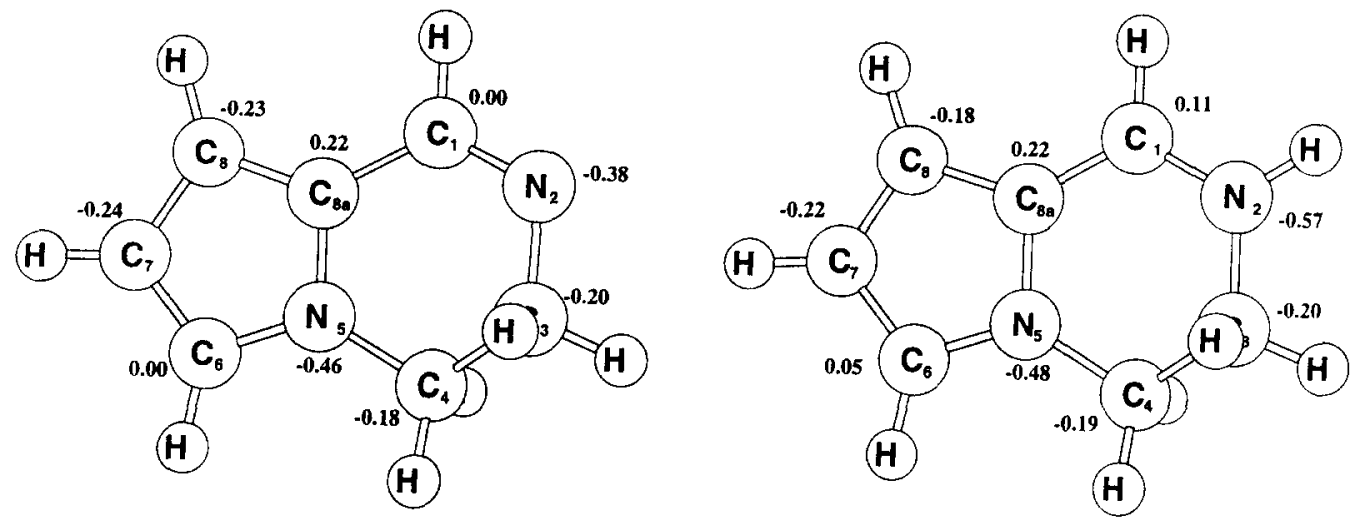

Figure 1. Optimized geometries and atomic charges for 3,4-dihydropyrrol[1,2-a]pyrazine (1) (left) and the Nprotonated form $1 \mathrm{a}$ (right) obtained at the $\mathrm{HF} / 6-31 \mathrm{G}^{* *}$ level.
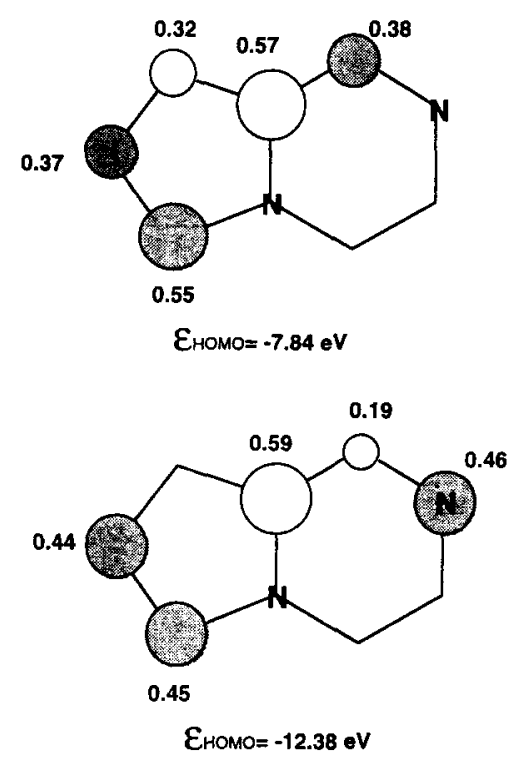

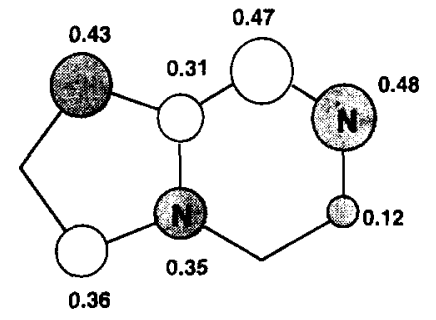

$\varepsilon_{\text {LUMO }}=3.00 \mathrm{eV}$

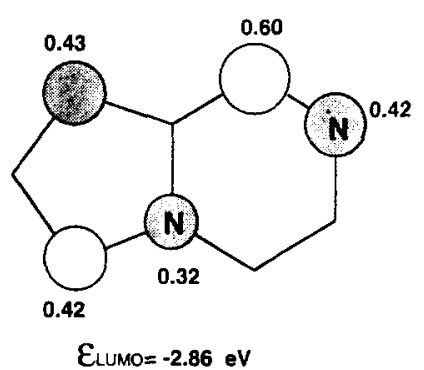

Figure 2. HOMO and LUMO of the 3,4-dihydropyrrolo[1,2-a]pyrazine (1) (above) and the N-protonated form 1a (below) with the orbital energies and the renormalized $\mathrm{HF} / 6-31 \mathrm{G}^{*}$ MO coefficients 
Table 1. Optimized Geometrical Parameters for 3,4-dihydropyrrolo[1,2-a]pyrazine (1)

\begin{tabular}{|c|c|c|c|c|c|}
\hline Bond lengths & $\mathrm{HF} / 6-31 \mathrm{G}^{*}$ & MP2/6-31G* & Bond angles & RHF/6-31G* & $\mathrm{MP} 2 / 6-31 \mathrm{G}^{*}$ \\
\hline $\mathrm{C8a}-\mathrm{Cl}$ & 1.458 & 1.445 & C8a-C1-N2 & 124.3 & 124.9 \\
\hline $\mathrm{Cl}-\mathrm{N} 2$ & 1.258 & 1.298 & $\mathrm{C} 1-\mathrm{N} 2-\mathrm{C} 3$ & 117.4 & 114.7 \\
\hline $\mathrm{N} 2-\mathrm{C} 3$ & 1.455 & 1.469 & $\mathrm{~N} 2-\mathrm{C} 3-\mathrm{C} 4$ & 114.8 & 114.2 \\
\hline $\mathrm{C} 3-\mathrm{C} 4$ & 1.528 & 1.525 & C3-C4-N5 & 108.5 & 107.5 \\
\hline C4-N5 & 1.488 & 1.455 & C4-N5-C8a & 120.2 & 119.4 \\
\hline N5-C8a & 1.364 & 1.378 & $\mathrm{~N} 5-\mathrm{C} 8 \mathrm{a}-\mathrm{Cl}$ & 117.8 & 117.8 \\
\hline N5-C6 & 1.353 & 1.366 & C8a-C8-C7 & 106.8 & 107.3 \\
\hline $\mathrm{C} 6-\mathrm{C} 7$ & 1.366 & 1.392 & C8-C7-C6 & 107.1 & 107.7 \\
\hline $\mathrm{C} 7-\mathrm{C} 8$ & 1.418 & 1.409 & C7-C6-N5 & 108.6 & 107.7 \\
\hline \multirow[t]{3}{*}{$\mathrm{C} 8-\mathrm{C} 8 \mathrm{a}$} & 1.365 & 1.397 & C6-N5-C8a & 109.1 & 109.9 \\
\hline & & & N5-C8a-C8 & 108.4 & 107.4 \\
\hline & & & C6-N5-C4 & 129.8 & 129.7 \\
\hline
\end{tabular}

a Bond lengths are in angstroms and bond angles in degrees

Table 2. Optimized Geometrical Parameters for N-Protonated 3,4-dihydropyrrolo[1,2-a]pyrazine (1a) ${ }^{a}$

\begin{tabular}{|c|c|c|c|c|c|}
\hline Bond lengths & $\mathrm{HF} / 6-31 \mathrm{G}^{*}$ & MP2/6-31G* & Bond angles & RHF/6-31G* & MP2/6-31G* \\
\hline$\overline{\mathrm{C} 8 \mathrm{a}-\mathrm{Cl}}$ & 1.384 & 1.396 & $\mathrm{C} 8 \mathrm{a}-\mathrm{C} 1-\mathrm{N} 2$ & 121.0 & 120.6 \\
\hline $\mathrm{Cl}-\mathrm{N} 2$ & 1.307 & 1.321 & $\mathrm{C} 1-\mathrm{N} 2-\mathrm{C} 3$ & 121.5 & 120.9 \\
\hline $\mathrm{N} 2-\mathrm{C} 3$ & 1.466 & 1.470 & $\mathrm{~N} 2-\mathrm{C} 3-\mathrm{C} 4$ & 110.6 & 109.7 \\
\hline $\mathrm{C} 3-\mathrm{C} 4$ & 1.528 & 1.522 & C3-C4-N5 & 108.5 & 107.7 \\
\hline C4-N5 & 1.457 & 1.462 & C4-N5-C8a & 120.7 & 120.5 \\
\hline N5-C8a & 1.386 & 1.386 & $\mathrm{~N} 5-\mathrm{C} 8 \mathrm{a}-\mathrm{C} 1$ & 119.3 & 118.9 \\
\hline N5-C6 & 1.324 & 1.354 & $\mathrm{C} 8 \mathrm{a}-\mathrm{C} 8-\mathrm{C} 7$ & 107.1 & 106.7 \\
\hline $\mathrm{C} 6-\mathrm{C} 7$ & 1.386 & 1.404 & $\mathrm{C} 8-\mathrm{C} 7-\mathrm{C} 6$ & 107.0 & 108.0 \\
\hline $\mathrm{C} 7-\mathrm{C} 8$ & 1.382 & 1.391 & C7-C6-N5 & 109.8 & 108.5 \\
\hline \multirow[t]{3}{*}{$\mathrm{C} 8-\mathrm{C} 8 \mathrm{a}$} & 1.398 & 1.414 & C6-N5-C8a & 108.5 & 108.9 \\
\hline & & & N5-C8a-C8 & 107.6 & 107.9 \\
\hline & & & C6-N5-C4 & 129.6 & 129.1 \\
\hline
\end{tabular}

\footnotetext{
${ }^{a}$ Bond lengths are in angstroms and bond angles in degrees
} 


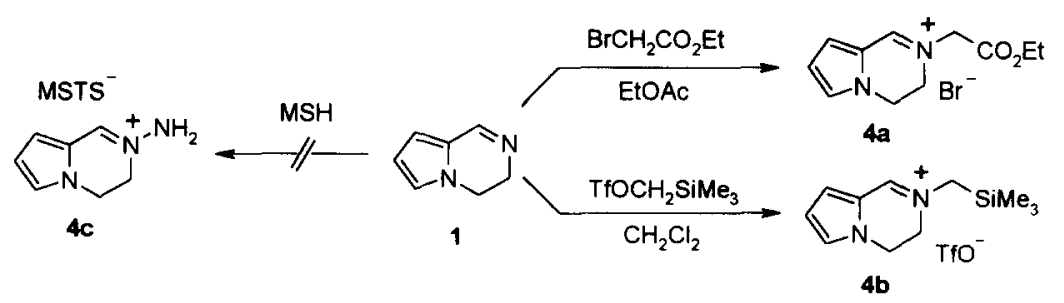

Scheme 2

latest experiments have shown it possible to trap the ylide $\mathbf{5}$ from $\mathbf{4 b}$ allowed us to trap $\mathbf{5}$ with dimethylacetylenedicarboxylate (DMAD) and methyl propiolate, although the best yields obtained for the 5,6-dihydrodipyrrolo $\left[1,2-a ; 2^{\prime}, 1^{\prime}-c\right]$ pyrazine derivatives 6 were less than $20 \%$. Moreover, although as stated earlier all our attempts to isolate and characterize the $\mathrm{N}$-amino salt $4 \mathrm{c}$ were unsuccessful, we were able to obtain ${ }^{1} \mathrm{H}$ NMR evidence that this salt had been formed. For this reason we tried to generate the aminide 7 in situ and react it with dipolarophiles. Only in the case of reaction with methyl propiolate were we able to isolate the cycloadduct 8 , albeit in low yield $(8 \%)$. This dihydroderivative was quantitatively oxidized to the corresponding 1-methoxycarbonyl-5,6dihydropyrazolo[1,5-a]pyrrolo[2,1-c]pyrazine (9) with 2,3-dichloro-1,4-benzoquinone (DDQ) in $\mathrm{CH}_{2} \mathrm{Cl}_{2}$. The reaction with other dipolarophiles (DMAD, acrylonitrile, methylmaleimide) afforded complex mixtures from which any possible cycloaddition products could not be detected.

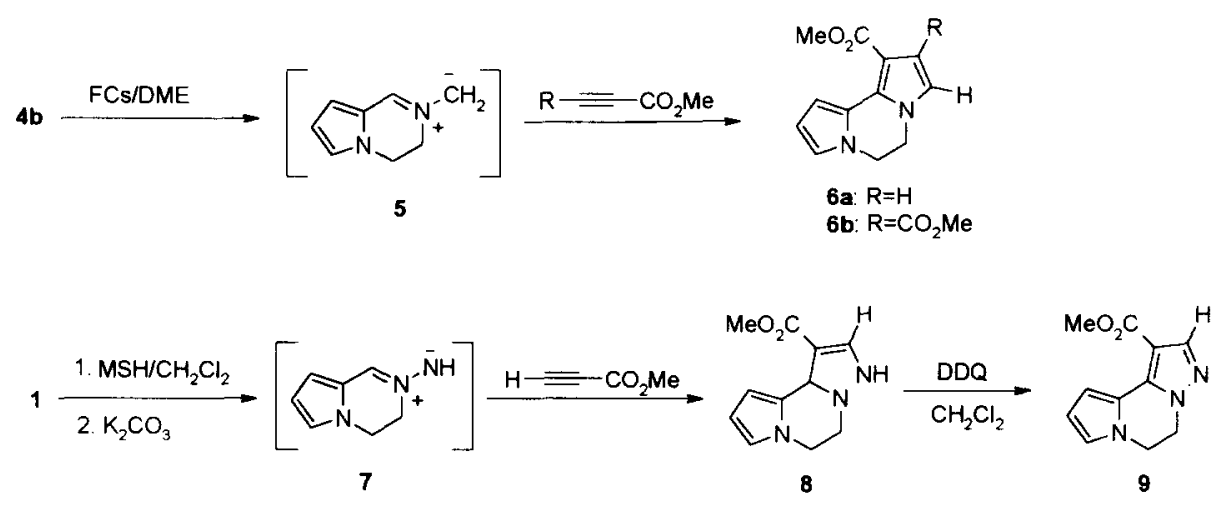

\section{Scheme 3}

The azomethine ylide 10, generated from 4a in a two-phase system, reacted with DMAD to yield a mixture of three compounds 11-13. Although the three components of the mixture could not be separated by chromatography, 'H NMR revealed the presence of the expected cycloaddition product 11, along with the more stable isomer 12, resulting from a 1,3-hydrogen shift. Both compounds oxidize easily to the major product, 13, and consequently this was the only compound to be chromatographically isolated. This was also the only compound obtained when the mixture was oxidized with DDQ in $\mathrm{CH}_{2} \mathrm{Cl}_{2}$. 
The regioselectivity of the cycloaddition was also investigated using unsymmetrical acetylenic dipolarophiles (ethyl and methyl propiolate) and electron-poor olefins (acrylonitrile). In both cases, the cycloadducts 14-16 had identical regiochemistry, corresponding to that predicted by FMO theory. While from the reaction of $4 a$ with propiolates only the fully aromatized derivatives $14 \mathbf{a}, \mathbf{b}$ were isolated, the reaction with acrylonitrile afforded a mixture of two compounds one of which, 15 , could be separated by chromatography. ${ }^{\prime} \mathrm{H}$ NMR shows that this
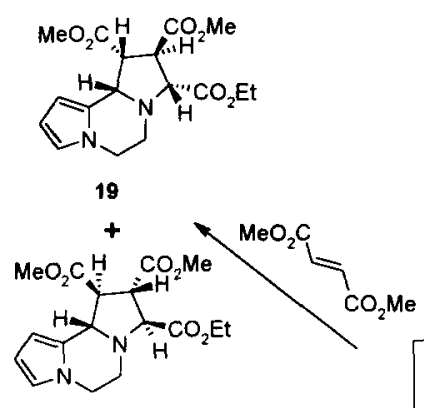

20

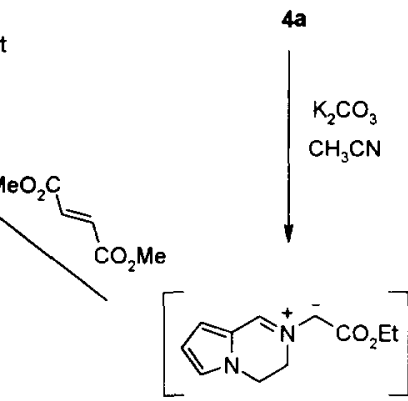

10

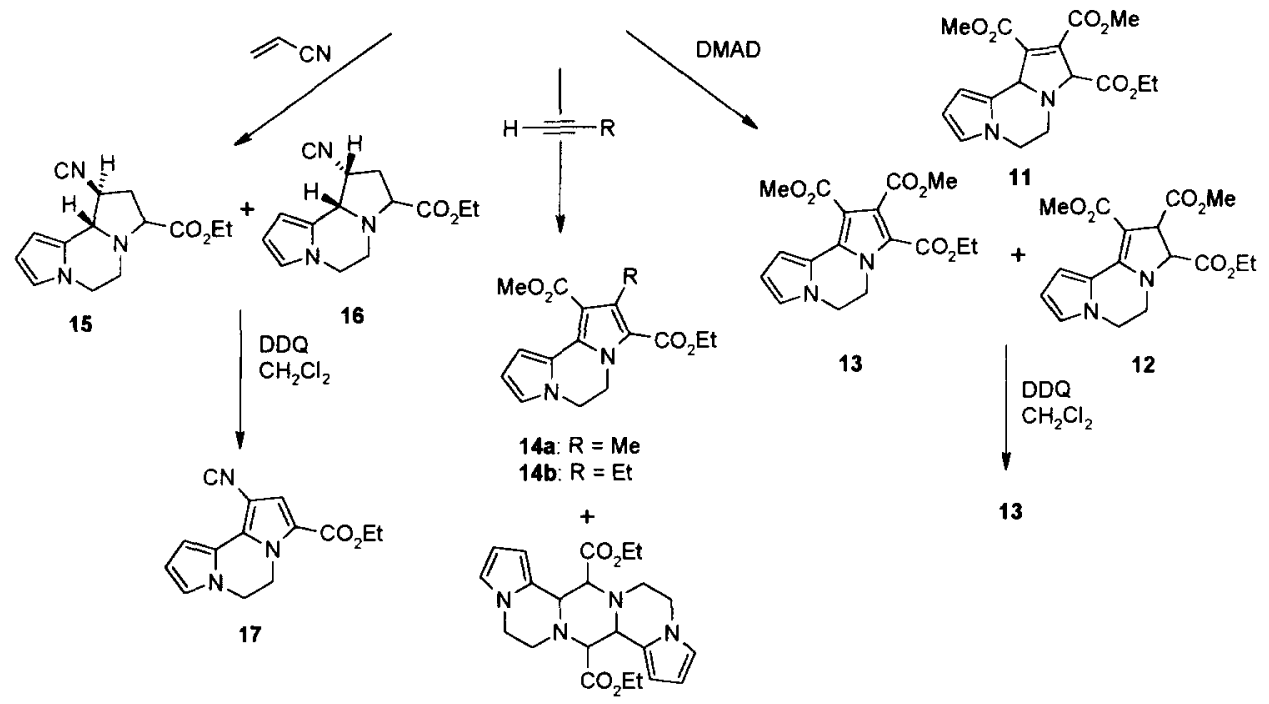

18

\section{Scheme 4}

compound corresponds to the $\mathrm{C}-1(\mathrm{CN})$ regioisomer (doublet for $\mathrm{H} 10 \mathrm{~b}$ and triplet for $\mathrm{H3}$ ) arising from an exo approach of $4 \mathrm{a}$ and the dipolarophile $\left(J_{1-10 \mathrm{~b}}=5.8 \mathrm{~Hz}\right)$. The ${ }^{1} \mathrm{H}$ NMR of the isomer 16, which could not be completely separated and purified by chromatography shows a coupling constant between $\mathrm{HI}$ and $\mathrm{H} 10 \mathrm{~b}$ of $J=8.2$ $\mathrm{Hz}$, which allowed the cis disposition to be assigned to these hydrogens in the cycloadduct, thus suggesting an endo approach during its formation. Oxidation of the mixture of 15 and 16 with DDQ gave the 1-cyano-3-ethoxy- 
carbonyl-5,6-dihydrodipyrrolo[1,2-a,2', 1'-c]pyrazine (17) in which $\mathrm{H} 2$ appeared at $\delta=7.16 \mathrm{ppm}$. It should be noted that the formation of the cycloadducts 14 is accompanied by variable amounts of the pentacyclic compound 18 . This compound which is ubiquitous, albeit in low yield, in all reactions involving the ylide $\mathbf{1 0}$ is formed by head-totail dimerization of this ylide, a favoured process when the iminium moiety, not integrated in the aromatic ring, shows high electrophilic character. Similar self-condensation reactions have been previously observed in the chemistry of related ylides. ${ }^{8,9}$

The stereoselectivity of the cycloaddition reaction of the ylide 10 was also studied using electron-poor alkenes. In the case of the reaction of $4 \mathrm{a}$ with dimethyl fumarate, a mixture of the trans 1,2-dicarboxylic esters 19 and 20 was obtained in $31 \%$ and $21 \%$ yieids respectively. The structure of these compounds was elucidated with the aid of ' $\mathrm{H}$ NMR decoupling experiments. In the endo cycloadduct 19, H1Ob appears as a doublet with a coupling constant of $J=8.1 \mathrm{~Hz}$ while the corresponding value for the exo product 20 is $J=6.0 \mathrm{~Hz}$. The coupling constant between $\mathrm{H} 1$ and $\mathrm{H}_{2}$ is.$=6.7 \mathrm{~Hz}$ for both compounds and in 19 and $20 \mathrm{H} 2$ is coupled to $\mathrm{H} 3$ with a coupling constant of $J=5.7 \mathrm{~Hz}$ and $J=5.9 \mathrm{~Hz}$ respectively, indicating a trans disposition in both compounds of the ethoxycarbonyl group at $\mathrm{C} 3$ with respect to the methoxycarbonyl substituent at $\mathrm{C} 2$. In contrast to this result, the reaction of methylmaleimide with $4 \mathrm{a}$ afforded the endo cycloadduct 21 as the only reaction product. The stereochemical assignment of 21 was based on the coupling constants observed between $\mathrm{H} 1 \mathrm{lb}$ and $\mathrm{H} 1 \mathrm{lc}(\mathrm{J}=8.0 \mathrm{~Hz})$ and $\mathrm{H} 1 \mathrm{lc}$ and $\mathrm{H} 3 \mathrm{a}(J=8.0 \mathrm{~Hz})$ which suggest a cis disposition for these hydrogens while a trans coupling constant $\mathrm{f} . J=2.0 \mathrm{~Hz}$ was observed for $\mathrm{H} 3 \mathrm{a}$ and $\mathrm{H} 4$.

More unusual products were formed from the reaction of $4 \mathbf{a}$ with heterocumulenes such as isothiocyanates and carbon sulphide. In the first case, the reaction of the ylide of 4a with methyl- and phenyl isothiocyanate would normally be expected to produce the corresponding heterobetaines $\mathbf{2 3}$, presumably via $\mathbf{2 2}$, as we previously found with pyrrolo[1,2-a]pyrazinium ylides ${ }^{10}$ and phenacyl salts of $4 \mathbf{a}^{3}$ In this case, however, the structure of the products is consistent with the heterobetaines 25 which must be formed by initial attack of $\mathrm{C}-1$ on the heterocumulene followed by cyclization of the intermediate 24 thus generated. ${ }^{11}$ This change in the regioselectivity between the phenacyl and ethoxycarbonylmethyl ylides is associated with the acidities of the hydrogens of the methylene groups in both compounds. Although the acidities are not known, those corresponding to the analogous pyridinium derivatives were reported by Bordwell and $\mathrm{col}^{12}{ }^{12}$ to have $\mathrm{pK}$ values of 14.10 for the ethoxycarbonylmethyl pyridinium salt and 10.7 for the phenacylpyridinium salt. In the light of this, differences in the ease of deprotonation between both salts are to be expected, which might affect the regioselectivity of the attack, especially if the intermediate is involved in a favourable intramolecular cyclization proccess. Whether the change in the regioselectivity observed between $4 \mathrm{a}$ and the corresponding $\mathrm{N}$-ethoxycarbonyl-pyrrolo[1,2-a]-pyrazinium salt could be associated with the electronic differences in both systems is not obvious, and the unusual behaviour should be further investigated. 


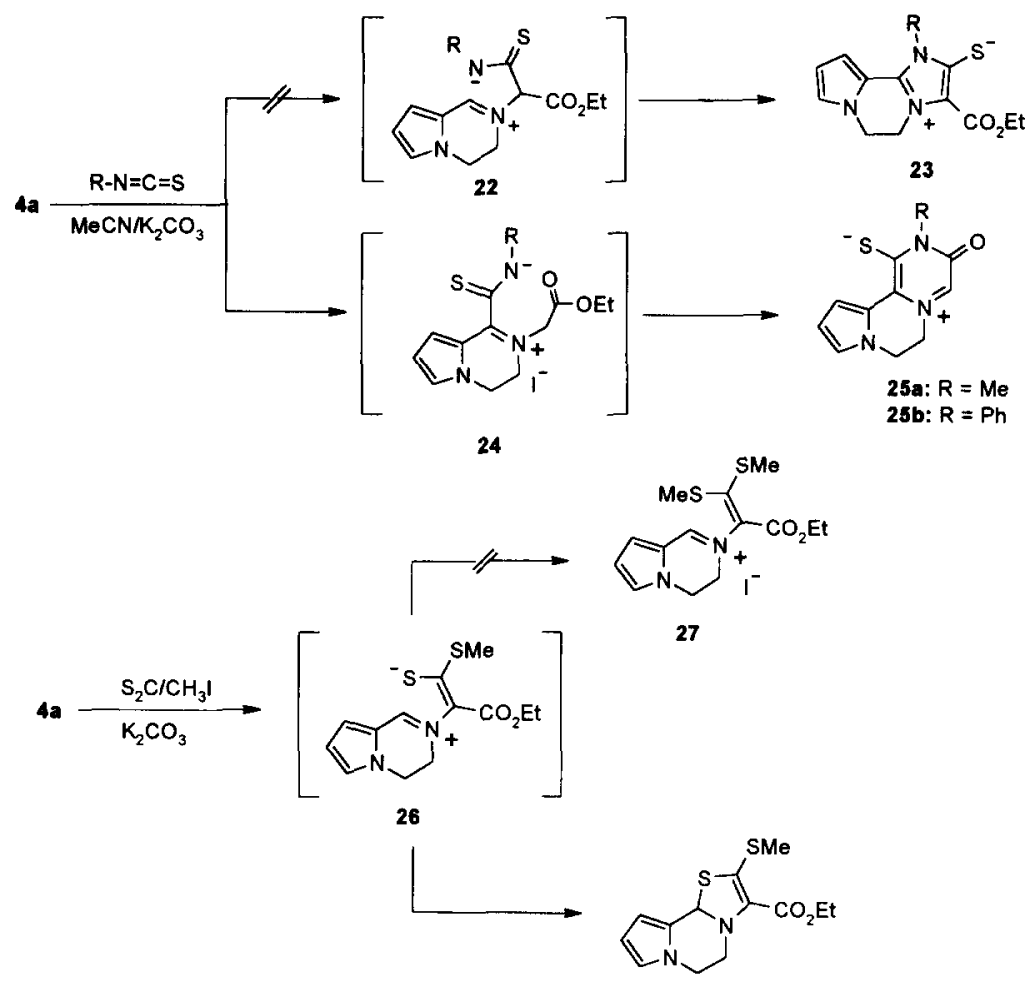

28

\section{Scheme 5}

On the other hand, the ketene diacetal 27 or the precursor ylide $\mathbf{2 6}$, which were the compounds expected from the reaction of $\mathbf{4 a}$ with carbon sulphide/methyl iodide ${ }^{11,13}$ were not detected, with the tricyclic derivative 28 being isolated in moderate yield. Here, the non-aromatic character of the dihydropyrazinium ring would explain the electrophilic behaviour of the $\mathrm{C} 1$ position towards intramolecular attack of the sulfur atom, to give rise to 28 .

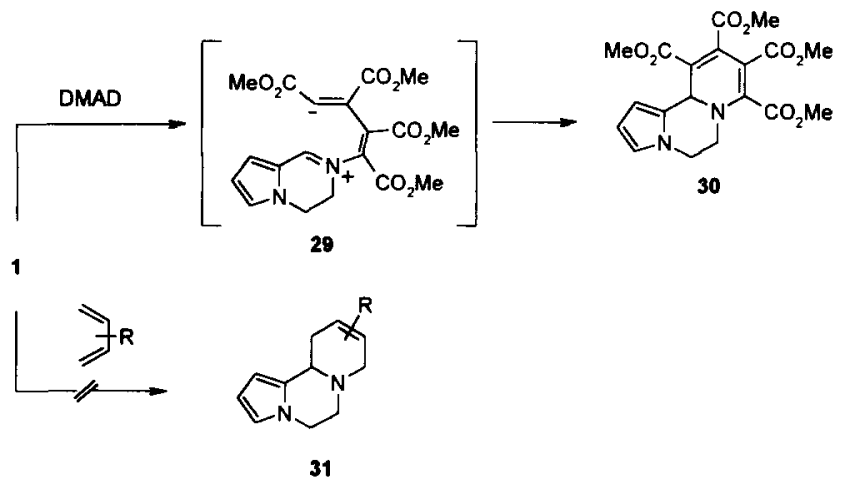

Scheme 6 
Both the nucleophilic character of the imine nitrogen and the lack of aromaticity of the pyrazine moiety in 1 explain the high yield of $30(61 \%)$ obtained in the reaction with DMAD. However, when 1 was tested as a dienophile in Diels-Alder processes with electron-rich dienes no traces of cycloadducts were detected. Under prolonging heating or Lewis acid catalysis, 1 extensively decomposed or gave polymeric materials. Electronpoor dienes were also tested and gave the same results.

Finally, intramolecular cycloaddition was also examined with different acetylenic and olefinic salts 32 and 33 which are suitable for intramolecular reactions. Salts 32 were prepared by $\mathrm{N}$-alkylation of 1 with methyl 4(iodoacetoxy)-2-butynoate (32a), 2-pentynoate (3), $^{3,14}$ ) and 3-iodoacetoxypropyne (32c) while 33 was obtained from the reaction of 1 and 3-[2-(iodoacetoxy)phenyl]acrylate. ${ }^{3}$ The treatment of salts 32a,b with $\mathrm{K}_{2} \mathrm{CO}_{3}$ in dry $\mathrm{MeCN}$, afforded the expected tetracyclic compounds 35a,b, albeit in low yields ( $24 \%$ and $30 \%$ respectively). All our attempts to improve the yields were unsuccessful since these salts seem to be rather unstable either under the two-phase liquid-liquid conditions or by refluxing in toluene or xylene under basic or neutral conditions. However, salt 32c, in which the acetylene was not activated by the presence of a carboxylate group, produced under the same conditions dimeric products related to 18 , with none of the expected cycloadduct being detected. Refluxing this salt in xylene gave similar results. As with 32c, the attempted intramolecular process with the ylide generated from 33 afforded dimeric products as the main components of a complex reaction mixture.

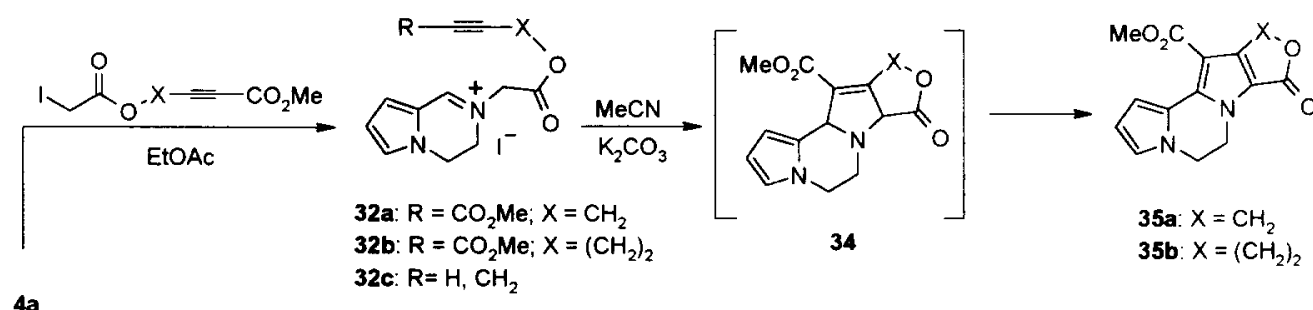

$4 a$

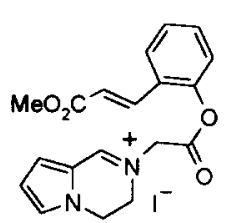

33

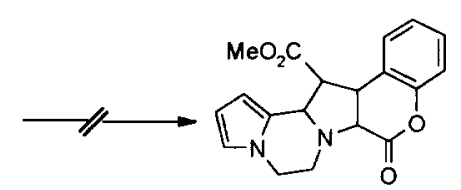

36

\section{Scheme 7}

In conclusion, the structure of the 3,4-dihydropyrrolo[1,2-a]pyrazine 1 and its protonated form has been studied by $a b$ initio calculations. The existence of a cyclic imine conjugated with a pyrrole moiety seems to generate a system which possesses a high electronic density nitrogen, which on quaternization should produce salts with a highly reactive carbon in the $\alpha$-position. The isolation and purification of 1 , as reported here, allowed the preparation of suitable salts which could be employed in either inter- or intramolecular cycloadditions 
to give novel tri- and tetracyclic systems containing two brigdehead nitrogens. In addition, based on the HOMO and LUMO energies calculated for this system, it was tested as a dienophile in [4+2] cycloadditions with appropriate dienes, with results which were however, unsuccessful in all cases.

\section{Experimental}

General Procedures. Melting points were determined on a Buchi SMP-20 apparatus and are uncorrected. 'H NMR were recorded on a Varian Unity 300 spectrometer and were referenced to TMS. IR spectra were obtained on a Perkin-Elmer 1310 spectrophotometer. Microanalyses were performed on a Heraeus CHN Rapid analyzer and MS were obtained on a Hewlett-Packard 5988 A spectrometer. Chromatography was performed on silica gel 60 (230-400 meshs). All reagents were obtained from commercial sources and were used as acquired. Solvents were dried before use. The 3,4-dihydropyrrolo[1,2-a]pyrazine (1) was prepared following the reported procedure and was purified by distillation under reduced pressure $\left(0.5 \mathrm{~mm} \mathrm{Hg}, 50^{\circ} \mathrm{C}\right)$. The colourless oil obtained was immediately used

2-[(Ethoxycarbonyl)methyl]-3,4-dihydropyrrolo[1,2-a]pyrazinium Bromide (4a). To $0.5 \mathrm{~g}$ (4.17 mmol) of

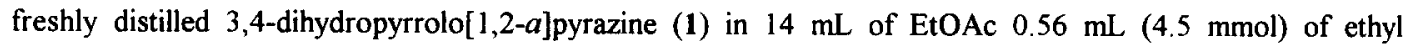
bromoacetate was added. The mixture was refluxed for $2 \mathrm{~h}$. The solvent was then evaporated under reduced pressure and the oily residue was triturated with $\mathrm{MeCN}$ and $\mathrm{Et}_{2} \mathrm{O}$ to give $0.7 \mathrm{~g}(61 \%)$ of a dark green solid which was recrystallized from EtOH. Mp 194-196 ${ }^{\circ} \mathrm{C}$; ${ }^{1} \mathrm{H}-\mathrm{NMR}\left(\mathrm{DMSO}^{-} \mathrm{d}_{6}\right) \delta 8.87(\mathrm{~s}, 1 \mathrm{H}) ; 7.83-7.79(\mathrm{~m}, 1 \mathrm{H}) ; 7.44$ (d. $1 \mathrm{H} ; \mathrm{J}=4.2 \mathrm{~Hz}$ ); $6.62(\mathrm{dd}, 1 \mathrm{H} ; \mathrm{J}=2.2 \mathrm{~Hz}, \mathrm{~J}=4.2 \mathrm{~Hz}) ; 4.88(\mathrm{~s}, 2 \mathrm{H}) ; 4.44(\mathrm{t}, 2 \mathrm{H}, \mathrm{J}=6.4 \mathrm{~Hz}) ; 4.21(\mathrm{q}, 2 \mathrm{H} ; \mathrm{J}=7.1 \mathrm{~Hz})$; $4.10(\mathrm{t}, 2 \mathrm{H}, \mathrm{J}=6.4 \mathrm{~Hz}) ; 1.24(\mathrm{t}, 3 \mathrm{H}, \mathrm{J}=7.1 \mathrm{~Hz}) \mathrm{ppm}$; IR (KBr) $v_{\max } 1741,1630,1347,1129 \mathrm{~cm}^{-1}$. Anal. Calcd for $\mathrm{C}_{11} \mathrm{H}_{15} \mathrm{BrN}_{2} \mathrm{O}_{2}: \mathrm{C}, 46.01 ; \mathrm{H}, 5.27 ; \mathrm{N}, 9.76$. Found: $\mathrm{C}, 46.23 ; \mathrm{H}, 5.08 ; \mathrm{N}, 9.80$.

2-(Trimethylsilyl)methyl]-3,4-dihydropyrrolo[1,2-aJpyrazinium Trifluoromethanesulfonate (4b). A mixture of $1(0.50 \mathrm{~g}, 4.1 \mathrm{mmol})$ and trimethylsilylmethyl trifluoromethane sulfonate $(0.98 \mathrm{~g}, 4.1 \mathrm{mmol})$ in $20 \mathrm{~mL}$ of dry $\mathrm{CH}_{2} \mathrm{Cl}_{2}$ was stirred at room temperature under argon for $4 \mathrm{~h}$. The solvent was removed under reduced pressure to leave a yellow solid which was filtered off and washed with $\mathrm{Et}_{2} \mathrm{O}$. Recrystallization from EtOH gave $1.11 \mathrm{~g} \mathrm{(77 \% )}$ of $4 \mathrm{~b}$ as a yellow powder. Mp $97-98^{\circ} \mathrm{C}$, ${ }^{\mathrm{H}} \mathrm{H}-\mathrm{NMR}\left(\mathrm{DMSO}-\mathrm{d}_{6}\right) \delta: 8.73(\mathrm{~s}, 1 \mathrm{H}) ; 7.64-7.61(\mathrm{~m}, 1 \mathrm{H}) ; 7.20(\mathrm{dd}, 1 \mathrm{H}$, $\mathrm{J}=2.2 \mathrm{~Hz}, \mathrm{~J}=1.3 \mathrm{~Hz}) ; 6.51(\mathrm{dd}, 1 \mathrm{H}, \mathrm{J}=2.2 \mathrm{~Hz}, \mathrm{~J}=4.0 \mathrm{~Hz}) ; 4.39(\mathrm{t}, 2 \mathrm{H}, \mathrm{J}=6.6 \mathrm{~Hz}) ; 4.04(\mathrm{t}, 2 \mathrm{H}, \mathrm{J}=6.6 \mathrm{~Hz}) ; 3.63(\mathrm{~s}$, $2 \mathrm{H}) ; 0.16(\mathrm{~s}, 9 \mathrm{H}) \mathrm{ppm} ; \mathrm{IR}(\mathrm{KBr}) \mathrm{u}_{\max } 3115,1631,1354,1262,1154,1030 \mathrm{~cm}^{-1}$. Anal. Calcd for $\mathrm{C}_{12} \mathrm{H}_{19} \mathrm{~F}_{3} \mathrm{~N}_{2} \mathrm{O}_{3} \mathrm{SSi}$ : C, 40.44; H, 5.37; N, 7.86. Found: C, 40.26; H, 5.39; N, 7.68.

1-Methoxycarbonyl-5,6-dihydrodipyrrolo[1,2-a;2', 1'-c]pyrazine (6a).To a mixture of $0.15 \mathrm{~g}(0.42 \mathrm{mmol})$ of $4 \mathrm{~b}$ in $10 \mathrm{~mL}$ of dry DME was added $64 \mathrm{mg}(0.42 \mathrm{mmol})$ of CsF and $35 \mathrm{mg}(0.42 \mathrm{mmol})$ of methyl propiolate. The mixture was refluxed under argon overnight. $\mathrm{CH}_{2} \mathrm{Cl}_{2}$ was then added and the organic phase was washed with $\mathrm{H}_{2} \mathrm{O}$ and brine $(2 \times 10 \mathrm{~mL})$. The organic extracts were dried over $\mathrm{Na}_{2} \mathrm{SO}_{4}$, filtered and evaporated to dryness. The oily residue was chromatographed using $\mathrm{CH}_{2} \mathrm{Cl}_{2}$ as eluent to give $16 \mathrm{mg}(18 \%)$ of $6 \mathrm{a}$ as a pale yellow oil. ${ }^{1} \mathrm{H}$-NMR $\left(\mathrm{CDCl}_{3}\right) \delta 7.31(\mathrm{dd}, 1 \mathrm{H}, \mathrm{J}=1.5 \mathrm{~Hz}, \mathrm{~J}=4.0 \mathrm{~Hz}) ; 6.69(\mathrm{dd}, 1 \mathrm{H}, \mathrm{J}=2.6 \mathrm{~Hz}, \mathrm{~J}=1.5 \mathrm{~Hz}) ; 6.62(\mathrm{~d}, 1 \mathrm{H}, \mathrm{J}=3.3 \mathrm{~Hz}) ; 6.53$ $(\mathrm{d}, 1 \mathrm{H}, \mathrm{J}=3.3 \mathrm{~Hz}) ; 6.25$ (dd, $1 \mathrm{H}, \mathrm{J}=2.6 \mathrm{~Hz}, \mathrm{~J}=4.0 \mathrm{~Hz}) ; 4.24-4.19(\mathrm{~m}, 4 \mathrm{H}) ; 3.84(\mathrm{~s}, 3 \mathrm{H}) \mathrm{ppm} ; \mathrm{IR}(\mathrm{KBr}) v_{\max } 1692$, 1438, 1208, 1140, $1075 \mathrm{~cm}^{-1}$; MS $m / z$ (rel int) $216(\mathrm{M}, 100) ; 185$ (85 ); 158 (19); 130 (14). Anal Calcd for $\mathrm{C}_{12} \mathrm{H}_{12} \mathrm{~N}_{2} \mathrm{O}_{2}: \mathrm{C}, 66.65 ; \mathrm{H}, 5.59 ; \mathrm{N}, 12.95$. Found: $\mathrm{C}, 66.49 ; \mathrm{H}, 5.64 ; \mathrm{N}, 12.67$ 
1,2-Dimethoxycarbonyl-5,6-dihydrodipyrrolo[1,2-a;2',1'-c]pyrazine (6b). To a mixture of $0.15 \mathrm{~g}(0.42$ $\mathrm{mmol})$ of $4 \mathrm{~b}$ in $10 \mathrm{~mL}$ of dry DME was added $64 \mathrm{mg}(0.42 \mathrm{mmol})$ of CsF and $60 \mathrm{mg}(0.42 \mathrm{mmol})$ of DMAD. The mixture was refluxed under argon overnight. $\mathrm{CH}_{2} \mathrm{Cl}_{2}$ was then added and the organic phase was washed with $\mathrm{H}_{2} \mathrm{O}$ and brine $(2 \times 10 \mathrm{~mL})$. The organic extracts were dried over $\mathrm{Na}_{2} \mathrm{SO}_{4}$ then filtered and evaporated. The oily residue was chromatographed (hexane-EtOAc, $1: 1)$ and the eluates rechromatographed $\left(\mathrm{CH}_{2} \mathrm{Cl}_{2}\right)$ to give $21 \mathrm{mg}(18 \%)$ of 6b as a colourless oil. ${ }^{1} \mathrm{H}-\mathrm{NMR}\left(\mathrm{CDCl}_{3}\right) \delta 7.14\left(\mathrm{~s}, 1 \mathrm{H}, \mathrm{H}_{3}\right) ; 6.86(\mathrm{dd}, 1 \mathrm{H}, \mathrm{J}=1.5 \mathrm{~Hz}, \mathrm{~J}=3.8 \mathrm{~Hz}) ; 6.68(\mathrm{dd}, 1 \mathrm{H}$, $\mathrm{J}=1.5 \mathrm{~Hz}, \mathrm{~J}=2.5 \mathrm{~Hz}$ ); $6.21(\mathrm{dd}, 1 \mathrm{H}, \mathrm{J}=3.8 \mathrm{~Hz}, \mathrm{~J}=2.5 \mathrm{~Hz}) ; 4.19(\mathrm{~s}, 4 \mathrm{H}) ; 3.87(\mathrm{~s}, 3 \mathrm{H}) ; 3.80(\mathrm{~s}, 3 \mathrm{H}) \mathrm{ppm}$; IR (KBr) $v_{\max } 1704,1486,1439,1203,1069 \mathrm{~cm}^{-1}$; MS $m / z$ (rel int) $274\left(\mathrm{M}^{+}, 95\right) ; 243$ (100); 213 (34); 184 (35); 157 (33). Anal. Calcd for $\mathrm{C}_{14} \mathrm{H}_{14} \mathrm{~N}_{2} \mathrm{O}_{4}: \mathrm{C}, 61.31 ; \mathrm{H}, 5.14 ; \mathrm{N}, 10.21$. Found: $\mathrm{C}, 61.18 ; \mathrm{H}, 5.00 ; \mathrm{N}, 10.52$.

\section{Generation of salt $4 \mathrm{c}$ and reaction with methyl propiolate}

To a solution of $0.23 \mathrm{~g}(1.1 \mathrm{mmol})$ of $\mathrm{MSH}$ in $5 \mathrm{~mL}$ of dry $\mathrm{CH}_{2} \mathrm{Cl}_{2}$ at $0^{\circ} \mathrm{C}$, was added $0.1 \mathrm{~g}(0.85 \mathrm{mmol})$ of

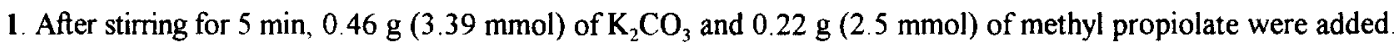
After stirring for $15 \mathrm{~h}$ at room temperature, the precipitate formed was filtered and washed with $\mathrm{CH}_{2} \mathrm{Cl}_{2}$. The filtrate was dried over $\mathrm{Na}_{2} \mathrm{SO}_{4}$ and evaporated to dryness. The residue was chromatographed (hexane-EtOAc 7:3) and the eluate subjected to a second chromatographic process $\left(\mathrm{CH}_{2} \mathrm{Cl}_{2}\right)$ affording $8(14 \mathrm{mg}, 8 \%)$ as a yellow oil.

1-Methoxycarbonyl-1,2,5,6-tetrahydropyrazolo[1,5-a]pyrrolo/2,1-c/pyrazine (8). ${ }^{1} \mathrm{H}-\mathrm{NMR}\left(\mathrm{CDCl}_{3}\right) \delta 6.82$ $(\mathrm{d}, 1 \mathrm{H}, \mathrm{J}=1.1 \mathrm{~Hz}) ; 6.5 \mathrm{l}(\mathrm{t}, 1 \mathrm{H}, \mathrm{J}=2 \mathrm{~Hz}) ; 6.16(\mathrm{dd}, 1 \mathrm{H}, \mathrm{J}=2.5 \mathrm{~Hz}, \mathrm{~J}=4.0 \mathrm{~Hz}) ; 5.96-5.94(\mathrm{~m}, 1 \mathrm{H}) ; 5.31(\mathrm{~s}, 1 \mathrm{H}) ; 4.10-$ $3.84(\mathrm{~m}, 4 \mathrm{H}) ; 3.77(\mathrm{~s}, 3 \mathrm{H}) ; 3.52-3.46(\mathrm{~m}, 1 \mathrm{H}) \mathrm{ppm}$; IR (KBr) $v_{\max } 1732,1588,1432,1038 \mathrm{~cm}^{-1}$; MS $\mathrm{m} / z$ (rel int) $219\left(\mathrm{M}^{+}, 59\right) ; 160(100) ; 159(95) ; 119(91)$.

1-Methoxycarbonyl-5,6-dihydropyrazolo[1,5-a]pyrrolo/2,1-c/pyrazine (9). Treatment of the dihydroderivative 8 with DDQ (16 $\mathrm{mg}, 0.07 \mathrm{~mol})$ in $\mathrm{CH}_{2} \mathrm{Cl}_{2}(2 \mathrm{~mL})$ yielded the aromatized compound 9 as a colourless oil. ' $\mathrm{H}-\mathrm{NMR}\left(\mathrm{CDCl}_{3}\right) \delta 7.90\left(\mathrm{~s}, 1 \mathrm{H}, \mathrm{H}_{2}\right) ; 7.37(\mathrm{dd}, 1 \mathrm{H}, \mathrm{J}=4.0 \mathrm{~Hz}, \mathrm{~J}=1.5 \mathrm{~Hz}) ; 6.80(\mathrm{dd}, 1 \mathrm{H}, \mathrm{J}=2.5 \mathrm{~Hz}, \mathrm{~J}=1.5 \mathrm{~Hz}$ ); $6.31(\mathrm{dd}, 1 \mathrm{H}, \mathrm{J}=4.0 \mathrm{~Hz}, \mathrm{~J}=2.5 \mathrm{~Hz}) ; 4.50-4.46(\mathrm{~m}, 2 \mathrm{H}) ; 4.35-4.31(\mathrm{~m} ., 2 \mathrm{H}) ; 3.87(\mathrm{~s}, 3 \mathrm{H}) \mathrm{ppm}$; IR (KBr) $v_{\max } 1705$, $1490,1208,1092 \mathrm{~cm}^{-1}$. Anal. Calcd for $\mathrm{C}_{11} \mathrm{H}_{11} \mathrm{~N}_{3} \mathrm{O}_{2}: \mathrm{C}, 60.82 ; \mathrm{H}, 5.10 ; \mathrm{N}, 19.34$. Found $\mathrm{C}, 60.49 ; \mathrm{H}, 5.38 ; \mathrm{N}$, 19.41

\section{Reaction of 4 a with DMAD}

To $0.25 \mathrm{~g}(0.87 \mathrm{mmol})$ of $4 \mathrm{a}$ in $15 \mathrm{~mL}$ of dry $\mathrm{CH}_{3} \mathrm{CN}$ were added $308 \mathrm{mg}(2.17 \mathrm{mmol})$ of DMAD and 480 $\mathrm{mg}$ ( $3.48 \mathrm{mmol}$ ) of anhydrous $\mathrm{K}_{2} \mathrm{CO}_{3}$. After stirring for $20 \mathrm{~h}$ at room temperature, the precipitate was filtered off and washed with $\mathrm{CH}_{2} \mathrm{Cl}_{2}$. The organic liquids were dried over $\mathrm{Na}_{2} \mathrm{SO}_{4}$ and evaporated and the oily residue was chromatographed. Elution with hexane-EtOAc (9:1) gave a mixture of the dihydroderivatives 11, 12 and the aromatized compound $13,183 \mathrm{mg}(61 \%)$. Treatment of the mixture with DDQ (120 mg, $0.52 \mathrm{mmol})$ in $10 \mathrm{~mL}$ of $\mathrm{CH}_{2} \mathrm{Cl}_{2}$ for $2 \mathrm{~h}$ gave 13 exclusively ( $146 \mathrm{mg}, 81 \%$ ) as a pale yellow solid.

3-Ethoxycarbonyl-1,2-dimethoxycarbonyl-5,6-dihydrodipyrrolo/1,2-a;2, $1^{\prime}$-clpyrazine (13). Mp 96-97 ${ }^{\circ} \mathrm{C}$ (EtOH); ${ }^{1} \mathrm{H}-\mathrm{NMR}\left(\mathrm{CDCl}_{3}\right) 87.38$ (dd, $\left.1 \mathrm{H}, \mathrm{J}=1.5 \mathrm{~Hz}, \mathrm{~J}=4.0 \mathrm{~Hz}\right) ; 6.77$ (dd, 1H, J=1.5 Hz, J=2.5 Hz); 6.28 (dd, $1 \mathrm{H}$, $\mathrm{J}=2.5 \mathrm{~Hz}, \mathrm{~J}=4.0 \mathrm{~Hz}) ; 4.78(\mathrm{t}, 2 \mathrm{H}, \mathrm{J}=6.1 \mathrm{~Hz}) ; 4.28(\mathrm{q}, 2 \mathrm{H}, \mathrm{J}=7.2 \mathrm{~Hz}) ; 4.22(\mathrm{t}, 2 \mathrm{H}, \mathrm{J}=6.1 \mathrm{~Hz}) ; 1.33(\mathrm{t}, 2 \mathrm{H}, \mathrm{J}=7.2 \mathrm{~Hz})$ ppm; IR (KBr) $v_{\max } 1705,1439,1257,1208 \mathrm{~cm}^{-1}$, MS $m / z$ (rel int) $346\left(\mathrm{M}^{+}, 100\right), 301$ (16), 243 (57), 211 (36), 184(38). Anal. Calcd for $\mathrm{C}_{17} \mathrm{H}_{18} \mathrm{~N}_{2} \mathrm{O}_{6}: \mathrm{C}, 58.96 ; \mathrm{H}, 5.24 ; \mathrm{N}, 8.09$. Found: $\mathrm{C}, 58.76 ; \mathrm{H}, 5.12 ; \mathrm{N}, 7.89$ 


\section{Reaction of $4 \mathrm{a}$ with alkyl propiolates}

To $0.2 \mathrm{~g}(0.69 \mathrm{mmol})$ of $4 \mathrm{a}$ in $12 \mathrm{~mL}$ of dry $\mathrm{MeCN}$ were added $0.38 \mathrm{~g}(2.78 \mathrm{mmol})$ of $\mathrm{K}_{2} \mathrm{CO}_{3}$ and $1.04 \mathrm{mmol}$ of methyl or ethyl propiolate. The reaction mixture was stirred at room temperature for $24 \mathrm{~h}$. Then the precipitate formed was filtered and washed with $\mathrm{CH}_{2} \mathrm{Cl}_{2}(3 \times 5 \mathrm{~mL})$. The combined organic extracts were dried over $\mathrm{Na}_{2} \mathrm{SO}_{4}$ and evaporated. Chromatography of the residue using a mixture of hexane-EtOAc (9:1) as eluent gave the corresponding cycloadducts $14 \mathbf{a}, \mathbf{b}$ and the dimeric derivative 18 .

3-Ethoxycarbonyl-1-methoxycarbonyl-5,6.dihydropyrrolo[1,2-a;2', '-c]pyrazine (14a). Yield: $54 \%$ Mp 131-132 ${ }^{\circ} \mathrm{C}$ (white needles, EtOH); ${ }^{1} \mathrm{H}-\mathrm{NMR}\left(\mathrm{CDCl}_{3}\right) \delta 7.46(\mathrm{dd}, 1 \mathrm{H}, \mathrm{J}=1.5 \mathrm{~Hz} ; \mathrm{J}=3.6 \mathrm{~Hz}) ; 7.44\left(\mathrm{~s}, 1 \mathrm{H}, \mathrm{H}_{2}\right) ; 6.76$ (dd, $1 \mathrm{H}, \mathrm{J}=2.5 \mathrm{~Hz}, \mathrm{~J}=1.5 \mathrm{~Hz}$ ); $6.28(\mathrm{dd}, 1 \mathrm{H}, \mathrm{J}=2.5 \mathrm{~Hz}, \mathrm{~J}=3.6 \mathrm{~Hz}) ; 4.81(\mathrm{t}, 2 \mathrm{H}, \mathrm{J}=6.1 \mathrm{~Hz}$ ); 4.29 (q, 2H, J=7.1 Hz); $4.23(\mathrm{t}, 2 \mathrm{H}, \mathrm{J}=6.1 \mathrm{~Hz}) ; 3.86(\mathrm{~s}, 3 \mathrm{H}) ; 1.36(\mathrm{t}, 2 \mathrm{H}, \mathrm{J}=7.1 \mathrm{~Hz}) \mathrm{ppm} ;{ }^{13} \mathrm{C}-\mathrm{NMR}\left(\mathrm{CDCl}_{3}\right) \delta 164.03\left(\mathrm{CO}_{2}\right) ; 161.08$ $\left(\mathrm{CO}_{2}\right) ; 133.81 ; 123.14 ; 121.97 ; 120.82 ; 120.22 ; 113.11 ; 109.53 ; 60.27 ; 51.14 ; 43.78 ; 43.05 ; 14.36 \mathrm{ppm}$; IR (KBr) $v_{\max } 1707,1685,1257,1203,1092 \mathrm{~cm}^{-1}$; MS $m / z$ (rel int) $288\left(\mathrm{M}^{+}, 100\right), 260$ (78), $229(81), 155$ (44). Anal. Calcd for $\mathrm{C}_{15} \mathrm{H}_{16} \mathrm{~N}_{2} \mathrm{O}_{4}: \mathrm{C}, 62.49 ; \mathrm{H}, 5.59 ; \mathrm{N}, 9.72$. Found: $\mathrm{C}, 62.36 ; \mathrm{H}, 5.35 ; \mathrm{N}, 9.48$.

1,3-Diethoxycarbonyl-5,6-dihydrodipyrrolo[1,2-a;2', I'-c/pyrazine (14b). Yield: $48 \%$. Mp 76-78 ${ }^{\circ} \mathrm{C}$ (white needles, EtOH); ${ }^{\mathrm{H}} \mathrm{H}-\mathrm{NMR}\left(\mathrm{CDCl}_{3}\right) \delta: 7.45(\mathrm{dd}, 1 \mathrm{H}, \mathrm{J}=1.5 \mathrm{~Hz}, \mathrm{~J}=3.9 \mathrm{~Hz}) ; 7.43\left(\mathrm{~s}, 1 \mathrm{H}, \mathrm{H}_{2}\right) ; 6.73(\mathrm{dd}, 1 \mathrm{H}, \mathrm{J}=1.5$ $\mathrm{Hz}, \mathrm{J}=2.5 \mathrm{~Hz}) ; 6.26(\mathrm{dd}, 1 \mathrm{H}, \mathrm{J}=2.5 \mathrm{~Hz}, \mathrm{~J}=3.9 \mathrm{~Hz}) ; 4.78(\mathrm{t}, 2 \mathrm{H}, \mathrm{J}=6.2 \mathrm{~Hz}) ; 4.33-4.21(\mathrm{~m}, 6 \mathrm{H}) ; 1.37$ (t, 3H, J=7.1 $\mathrm{Hz}$ ); 1.35 (t, 3H, J=7.1 Hz) ppm; IR (KBr) $v_{\max } 1693,1479,1255,1202,1159 \mathrm{~cm}^{-1} ; \mathrm{MS} m / z$ (rel int) $302\left(\mathrm{M}^{+}, 100\right)$, 274 (31), 246 (59), 229 (31), 202 (15). Anal. Calcd for $\mathrm{C}_{16} \mathrm{H}_{18} \mathrm{~N}_{2} \mathrm{O}_{4}: \mathrm{C}, 63.57 ; \mathrm{H}, 6.00 ; \mathrm{N}, 9.27$. Found: C, 63.11; $\mathrm{H}, 6.43 ; \mathrm{N}, 8.98$

8,16-Diethoxycarbonyl-5,6,8,8a,13,14,16,16a-octahydrodipyrrolo[1,2-a]pyrazinio[2,1-a:2',1'-d]pyrazine (18). Yield: 11\%. Mp 241-243 ${ }^{\circ} \mathrm{C}$ (white powder, EtOH); ${ }^{1} \mathrm{H}-\mathrm{NMR}\left(\mathrm{CDCl}_{3}\right) \delta 6.58(\mathrm{~d}, 1 \mathrm{H}, J=3.0 \mathrm{~Hz}) ; 6.54-6.52$ (m, $1 \mathrm{H}) ; 6.31(\mathrm{~d}, 1 \mathrm{H}, J=2.5 \mathrm{~Hz}) ; 6.15-6.12(\mathrm{~m}, 2 \mathrm{H}) ; 5.23$ (s, 1H); 4.23-3.89 (m, $10 \mathrm{H}) ; 3.70$ (d, 1H, J=16.4 Hz); 3.44 (d, 1H, $J=16.4 \mathrm{~Hz}) ; 3.41-3.33(\mathrm{~m}, 1 \mathrm{H}) ; 3.21-3.16(\mathrm{~m}, 2 \mathrm{H}) ; 2.99$ (td, $1 \mathrm{H}, J=11.4,4.4 \mathrm{~Hz}) \mathrm{ppm}$; IR (KBr) $v_{\max }$ $1722,1640,1404,1283 \mathrm{~cm}^{-1}$; MS $m / z$ (rel int) 412(M, 62), 339 (53), 325 (32), 220 (100). Anal. Calcd for $\mathrm{C}_{22} \mathrm{H}_{28} \mathrm{~N}_{4} \mathrm{O}_{4}: \mathrm{C}, 64.06 ; \mathrm{H}, 6.84 ; \mathrm{N}, 13.58$. Found: $\mathrm{C}, 63.87 ; \mathrm{H}, 6.90 ; \mathrm{N}, 13.47$.

\section{Reaction of $4 \mathrm{a}$ with acrylonitrile}

To $0.4 \mathrm{~g}(1.39 \mathrm{mmol})$ of $4 \mathrm{a}$ in $15 \mathrm{~mL}$ of dry $\mathrm{MeCN}$ was added $0.77 \mathrm{~g}(5.57 \mathrm{mmol})$ of $\mathrm{K}_{2} \mathrm{CO}_{3}$ and $110 \mathrm{mg} \mathrm{(2}$ $\mathrm{mmol}$ ) of acrylonitrile. The reaction was stirred for $30 \mathrm{~h}$ at room temperature, the precipitate formed was filtered off and the organic phase dried over $\mathrm{Na}_{2} \mathrm{SO}_{4}$ and evaporated under reduced pressure. Chromatography of the residue using hexane-EtOAc (8:2) as eluent gave a mixture of the tetrahydroderivatives 15 and $16(144 \mathrm{mg}, 81 \%)$. Chromatography of the mixture allowed the separation of $33 \mathrm{mg}$ of 15 as a colourless oil. Treatment of the mixture of 15 and 16 with DDQ ( $252 \mathrm{mg}, 1.11 \mathrm{mmol}$ ) in $5 \mathrm{~mL}$ of $\mathrm{CH}_{2} \mathrm{Cl}_{2}$ for $1 \mathrm{~h}$ afforded the aromatized derivative 17 (88 $\mathrm{mg}, 62 \%)$ as a white solid.

I-Cyano(IR,10bR)- and (IS, 10bS)-3-ethoxycarbonyl-1,2,3,5,6,10b-hexahydrodipyrrolo[1,2-a;2', $\left.1^{\prime}-c\right]-$ pyrazine [( $( \pm) 15] .{ }^{1} \mathrm{H}-\mathrm{NMR}\left(\mathrm{CDCl}_{3}\right) \delta: 6.61(\mathrm{t}, 1 \mathrm{H}, \mathrm{J}=2 \mathrm{~Hz}) ; 6.19-6.17(\mathrm{~m}, 2 \mathrm{H}) ; 4.60\left(\mathrm{~d}, 1 \mathrm{H}, \mathrm{H}_{106}, \mathrm{~J}=5.9 \mathrm{~Hz}\right) ; 4.19$ (q, $2 \mathrm{H}, \mathrm{J}=7.0 \mathrm{~Hz}) ; 4.12-4.05(\mathrm{~m}, 1 \mathrm{H}) ; 3.93-3.87(\mathrm{~m}, 2 \mathrm{H}) ; 3.43\left(\mathrm{q}, 1 \mathrm{H}, \mathrm{H}_{1}, \mathrm{~J}=6.0 \mathrm{~Hz}\right) ; 3.34-3.26(\mathrm{~m}, 2 \mathrm{H}) ; 2.52-$ $2.45(\mathrm{~m}, 2 \mathrm{H}) ; 1.28(\mathrm{t}, 3 \mathrm{H}, \mathrm{J}=7.0 \mathrm{~Hz}) ; \mathbb{R}(\mathrm{KBr}) \mathrm{v}_{\max } 2243,1731,1450,1189 \mathrm{~cm}^{-1}$.

1-Cyano-3-ethoxycarbonyl-5, 6-dihydrodipyrrolol 1,2-a;2', 1'-c/pyrazine (17). Mp $154-155^{\circ} \mathrm{C}$ (EtOH); ${ }^{1} \mathrm{H}$ $\operatorname{NMR}\left(\mathrm{CDCl}_{3}\right) \delta 7.16\left(\mathrm{~s}, 1 \mathrm{H}, \mathrm{H}_{2}\right) ; 6.94$ (dd, $\left.1 \mathrm{H}, \mathrm{J}=1.5 \mathrm{~Hz}, \mathrm{~J}=4.0 \mathrm{~Hz}\right) ; 6.77$ (dd, $1 \mathrm{H}, \mathrm{J}=1.5 \mathrm{~Hz}, \mathrm{~J}=2.5 \mathrm{~Hz}$ ); 6.30 (dd, $1 \mathrm{H}, \mathrm{J}=2.5 \mathrm{~Hz}, \mathrm{~J}=4.0 \mathrm{~Hz}) ; 4.79(\mathrm{t}, 2 \mathrm{H}, \mathrm{J}=6.2 \mathrm{~Hz}) ; 4.29(\mathrm{q}, 2 \mathrm{H}, \mathrm{J}=7.0 \mathrm{~Hz}) ; 4.24(\mathrm{t}, 2 \mathrm{H}, \mathrm{J}=6.2 \mathrm{~Hz}) ; 1.35(\mathrm{t}, 3 \mathrm{H}, \mathrm{J}=7.0$ 
$\mathrm{Hz}$ ) ppm; IR (KBr) $v_{\max } 2219,1699,1479,1255,1098 \mathrm{~cm}^{-1} \mathrm{ppm}$; MS $m / z$ (rel int) $255\left(\mathrm{M}^{+}, 93\right) ; 227$ (100); 182 (70); 180 (45); 129 (54); Anal Calcd for $\mathrm{C}_{14} \mathrm{H}_{13} \mathrm{~N}_{3} \mathrm{O}_{2}: \mathrm{C}, 65.87 ; \mathrm{H}, 5.13 ; \mathrm{N}, 16.46$; Found : C, 65.54; H, 5.18; N, 16.29 .

\section{Reaction of $4 \mathrm{a}$ with dimethyl fumarate}

To a mixture of $0.4 \mathrm{~g}(1.4 \mathrm{mmol})$ of $4 \mathrm{a}$ in $15 \mathrm{~mL}$ of dry MeCN was added $0.77 \mathrm{~g}(5.57 \mathrm{mmol})$ of anhydrous $\mathrm{K}_{2} \mathrm{CO}_{3}$ and $0.24 \mathrm{~g}(1.67 \mathrm{mmol})$ of dimethyl fumarate. The reaction was stirred at room temperature for $30 \mathrm{~h}$. Then, the precipitate was filtered and washed with $\mathrm{CH}_{2} \mathrm{Cl}_{2}$. The combined organic phases were dried over $\mathrm{Na}_{2} \mathrm{SO}_{4}$ and evaporated under reduced pressure. The oily residue was chromatographed using hexane-EtOAc (1:1) as eluent to give a 60:40 mixture of 19 and 20. Recrystallization of the mixture from ethanol gave 19 as a white solid (150 $\mathrm{mg}(31 \%)$. From the mother liquids compound 20 was isolated as a colourless oil (100 $\mathrm{mg}, 21 \%$ ).

I,2-Dimethoxycarbonyl (IR,2S,10bS)- and (IS,2R,10bR)-3-ethoxycarbonyl-1,2,3,5,6,10b-hexahydrodipyrrolol I,2-a;2, $1^{\prime}$-clpyrazine [(土)-19]. Mp 106-108 ${ }^{\circ} \mathrm{C}(\mathrm{EtOH}) ;{ }^{1} \mathrm{H}-\mathrm{NMR}\left(\mathrm{CDCl}_{3}\right) \delta$ 6.55-6.51 (m, 1H); 6.08 (dd, $1 \mathrm{H}, \mathrm{J}=2.5 \mathrm{~Hz}, \mathrm{~J}=3.6 \mathrm{~Hz}) ; 5.75(\mathrm{dd}, \mathrm{lH}, \mathrm{J}=2.5 \mathrm{~Hz}, \mathrm{~J}=1.3 \mathrm{~Hz}) ; 4.93\left(\mathrm{~d}, 1 \mathrm{H}, \mathrm{H}_{10 \mathrm{~b}}, \mathrm{~J}=8.1 \mathrm{~Hz}\right) ; 4.21-4.13(\mathrm{~m}, 3 \mathrm{H})$; 4 08-4.01 (m, 1H);3.95-3.84 (m, 2H); 3.78-3.70 ( m, 1H, H $)$; 3.67 (s, 3H); $3.62(\mathrm{~s}, 3 \mathrm{H}) ; 3.40-3.32(\mathrm{~m}, 1 \mathrm{H}) ; 3.19-$ $3.10(\mathrm{~m}, 1 \mathrm{H}) ; 1.17(\mathrm{t}, 3 \mathrm{H}, \mathrm{J}=7.1 \mathrm{~Hz}) \mathrm{ppm}$; IR (KBr) $v_{\max } 1724,1375,1236,1183 \mathrm{~cm}^{-1}$; MS m/z (rel int) $350\left(\mathrm{M}^{+}\right.$, 6); 245 (13); 206 (41); 192 (39); 158 (44); Anal Calcd for $\mathrm{C}_{17} \mathrm{H}_{22} \mathrm{~N}_{2} \mathrm{O}_{6}: \mathrm{C}, 58.28 ; \mathrm{H}, 6.33 ; \mathrm{N}, 8.00$. Found: C, $58.29 ; \mathrm{H}, 6.31 ; \mathrm{N}, 7.88$.

1,2-Dimethoxycarbonyl (IR, 2S,3R,10bR)- and (IS,2R,3S,10bS)-3-ethoxycarbonyl-1,2-3,5,6-hexahydrodipyrrolo/l,2-a:2', I'-c/pyrazine [( $( \pm)-20] .{ }^{~} \mathrm{H}-\mathrm{NMR}\left(\mathrm{CDCl}_{3}\right) \delta: 6.57-6.54(\mathrm{~m}, 1 \mathrm{H}) ; 6.11(\mathrm{dd}, \mathrm{lH}, \mathrm{J}=2.5 \mathrm{~Hz}, \mathrm{~J}=3.6$ $\mathrm{Hz}) ; 5.92(\mathrm{dd}, 1 \mathrm{H}, \mathrm{J}=1.5 \mathrm{~Hz}, \mathrm{~J}=2.5 \mathrm{~Hz}) ; 4.74\left(\mathrm{~d}, 1 \mathrm{H}, \mathrm{H}_{\mathrm{tob}}, \mathrm{J}=5.9 \mathrm{~Hz}\right) ; 4.28-4.18(\mathrm{~m}, 2 \mathrm{H}) ; 4.08\left(\mathrm{~d}, 1 \mathrm{H}, \mathrm{H}_{3}, \mathrm{~J}=5.9\right.$ $\mathrm{Hz}) ; 4.07-4.01(\mathrm{~m}, 1 \mathrm{H}) ; 3.89-3.82(\mathrm{~m}, 2 \mathrm{H}) ; 3.79(\mathrm{~s}, 3 \mathrm{H}) ; 3.63(\mathrm{~s}, 3 \mathrm{H}) ; 3.47\left(\mathrm{dd}, 1 \mathrm{H}, \mathrm{H}_{\mathrm{l}}, \mathrm{J}_{1-10 \mathrm{~b}}=5.9 \mathrm{~Hz}, \mathrm{~J}_{1-2}=6.5\right.$ $\mathrm{Hz}) ; 3.30-3.25(\mathrm{~m}, 2 \mathrm{H}) ; 1.29(\mathrm{t}, 3 \mathrm{H} ; \mathrm{J}=7.2 \mathrm{~Hz}) \mathrm{ppm}$; IR (KBr) $v_{\max } 1720,1438,1340,1166 \mathrm{~cm}^{-1}$

\section{Reaction of $4 \mathrm{a}$ with $\mathbf{N}$-methylmaleimide}

4-Ethoxycarbonyl-2-methyl-1,3-dioxo-3a, 4,6,7,11b, 11c-hexahydropyrrolo/3',4':3,4]pyrrlo/1,2-a]pyrrolo/2,1-c/pyrazine (21). To a stirred two phase mixture of $4 \mathrm{a}(0.25 \mathrm{~g}, 0.87 \mathrm{mmol})$ in dry $\mathrm{MeCN}(10 \mathrm{~mL})$ and $\mathrm{K}_{2} \mathrm{CO}_{3}$ (480 mg, $3.48 \mathrm{mmol}$ ), was added $\mathrm{N}$-methylmaleimide $(193 \mathrm{mg}, 1.74 \mathrm{mmol}$ ) and stirring was continued at room temperature for $15 \mathrm{~h}$; then the precipitate was filtered and washed with $\mathrm{CH}_{2} \mathrm{Cl}_{2}(3 \times 5 \mathrm{~mL})$. The combined organic phases were dried over $\mathrm{Na}_{2} \mathrm{SO}_{4}$ and evaporated to give a residue which was chromatographed using a mixture of hexane-EtOAc (7:3) yielding $158 \mathrm{mg}(57 \%)$ of a white solid. $\mathrm{Mp} 147-148^{\circ} \mathrm{C}(\mathrm{EtOH}) ;{ }^{\mathrm{l}} \mathrm{H}-\mathrm{NMR}\left(\mathrm{CDCl}_{3}\right)$ $\delta$ 6.55-6.52 (m, 1H); 6.21 (dd, $1 \mathrm{H}, \mathrm{J}=1.5 \mathrm{~Hz}, \mathrm{~J}=2.5 \mathrm{~Hz}) ; 6.16$ (dd, $1 \mathrm{H}, \mathrm{J}=2.5 \mathrm{~Hz}, \mathrm{~J}=4.0 \mathrm{~Hz}) ; 4.43\left(\mathrm{~d}, 1 \mathrm{H}, \mathrm{H}_{10 \mathrm{~b}}\right.$, $\mathrm{J}=8.0 \mathrm{~Hz}) ; 4.23(\mathrm{q}, 2 \mathrm{H}, \mathrm{J}=7.2 \mathrm{~Hz}) ; 4.21\left(\mathrm{~d}, 1 \mathrm{H}, \mathrm{H}_{3}, \mathrm{~J}=2.0 \mathrm{~Hz}\right) ; 3.96-3.85(\mathrm{~m}, 2 \mathrm{H}) ; 3.66\left(\mathrm{t}, 1 \mathrm{H}, \mathrm{H}_{1}, \mathrm{~J}=8.0 \mathrm{~Hz}\right) ;$ $3.60\left(\mathrm{dd}, 1 \mathrm{H}, \mathrm{H}_{2}, \mathrm{~J}_{2-106}=8.0 \mathrm{~Hz}, \mathrm{~J}_{2-3}=2.0 \mathrm{~Hz}\right) ; 3.29-3.23(\mathrm{~m}, 1 \mathrm{H}) ; 3.09-3.04(\mathrm{~m}, 1 \mathrm{H}) ; 2.90(\mathrm{~s}, 3 \mathrm{H}) ; 1.32(\mathrm{t}, 3 \mathrm{H}$, $\mathrm{J}=7.2 \mathrm{~Hz}) \mathrm{ppm} ;{ }^{13} \mathrm{C}-\mathrm{NMR}\left(\mathrm{CDCl}_{3}\right) \delta: 177.42(\mathrm{CO}) ; 174.64(\mathrm{CO}) ; 169.50(\mathrm{CO} 2) ; 123.90 ; 119.13 ; 107.99 ; 106.36$; $65.40 ; 61.41 ; 59.10 ; 48.13 ; 46.87 ; 45.16 ; 44.30 ; 25.23 ; 14.38$ ppm; IR (KBr) $v_{\max } 1721,1692,1430,1244,1122$ $\mathrm{cm}^{-1}$, MS m/z (rel int) $317\left(\mathrm{M}^{+}, 12\right), 288(38), 244(24), 206(35), 159$ (38). Anal Calcd for $\mathrm{C}_{16} \mathrm{H}_{19} \mathrm{~N}_{3} \mathrm{O}_{4}: \mathrm{C}, 6056$; $\mathrm{H}, 6.03 ; \mathrm{N}, 13.24$. Found: $\mathrm{C}, 61.89 ; \mathrm{H}, 6.02 ; \mathrm{N}, 12.84$.

\section{Reaction of $4 \mathrm{a}$ with isothiocyanates}

To a stirred two phase mixture of $4 \mathrm{a}(0.2 \mathrm{~g}, 0.7 \mathrm{mmol})$ in $10 \mathrm{~mL}$ of dry $\mathrm{MeCN}$ and anhydrous $\mathrm{K}_{2} \mathrm{CO}_{3}(0.38$, 
$2.8 \mathrm{mmol}$ ) methyl- or phenylisothiocyanate was added $(2 \mathrm{mmol})$ and stirring was continued at room temperature for $70 \mathrm{~h}$. The precipitate was filtered off and washed with $\mathrm{CH}_{2} \mathrm{Cl}_{2}(3 \times 5 \mathrm{~mL})$. The organic phase was dried over $\mathrm{Na}_{2} \mathrm{SO}_{4}$ and evaporated under reduced pressure. Chromatography (hexane-EtOAc 9:1 as eluent for 25a and $\mathrm{CH}_{2} \mathrm{Cl}_{2}$ for 25b) gave pure heterobetaines .

2-Methyl-3-oxo-6,7-dihydropyrazinio[1,2-a]pyrrolo/2,1-c]pyrazin-5-ium-1-thiolate (25a). Yield:21\%. Mp $187-189^{\circ} \mathrm{C}\left(\mathrm{EtOH}\right.$, orange powder); ${ }^{1} \mathrm{H}-\mathrm{NMR}\left(\mathrm{CDCl}_{3}\right) \delta: 6.89(\mathrm{dd}, 1 \mathrm{H}, \mathrm{J}=1.5 \mathrm{~Hz}, \mathrm{~J}=2.5 \mathrm{~Hz}) ; 6.79(\mathrm{~s}, 1 \mathrm{H}) ; 6.60$ (dd, $1 \mathrm{H}, \mathrm{J}=1.5 \mathrm{~Hz}, \mathrm{~J}=4.0 \mathrm{~Hz}$ ); 6.25 (dd, $1 \mathrm{H}, \mathrm{J}=2.5 \mathrm{~Hz}, \mathrm{~J}=4.0 \mathrm{~Hz}$ ); 4.80-4.42 (bs, 2H); 4.38-4.29 (m, 2H); 3.37 (s, 3H) ppm; ${ }^{13} \mathrm{C}-\mathrm{NMR}\left(\mathrm{CDCl}_{3}\right) \delta 175.60 ; 163.27 ; 129.70 ; 128.57 ; 122.24 ; 119.59 ; 110.91 ; 105.82 ; 48.92 ; 45.79$;

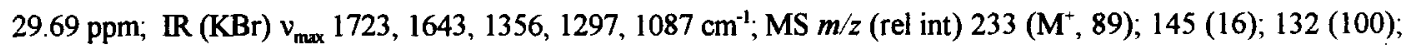
131 (77); 105 (40). Anal Calcd for $\mathrm{C}_{11} \mathrm{H}_{11} \mathrm{~N}_{3} \mathrm{OS}: \mathrm{C}, 56.63 ; \mathrm{H}, 4.75 ; \mathrm{N}, 18.01$. Found: $\mathrm{C}, 56.21 ; \mathrm{H}, 4.72 ; \mathrm{N}, 17.89$.

3-Oxo-2-phenyl-6, 7-dihydropyrazinio[1,2-a]pyrrolo[2,1-c]pyrazin-5-ium-I-thiolate (25b). Yield: 49\%.Mp 237-238 ${ }^{\circ} \mathrm{C}$ (hexane- $\mathrm{CH}_{2} \mathrm{Cl}_{2}$, yellow plates); ${ }^{\prime} \mathrm{H}-\mathrm{NMR}\left(\mathrm{CDCl}_{3}\right) \delta: 7.52-7.45(\mathrm{~m}, 3 \mathrm{H}) ; 7.39-7.36(\mathrm{~m}, 2 \mathrm{H}) ; 6.94(\mathrm{dd}$, $1 \mathrm{H}, \mathrm{J}=1.5 \mathrm{~Hz}, \mathrm{~J}=2.5 \mathrm{~Hz}) ; 6.87(\mathrm{~s}, 1 \mathrm{H}) ; 6.64(\mathrm{dd}, 1 \mathrm{H}, \mathrm{J}=1.5 \mathrm{~Hz}, \mathrm{~J}=4.0 \mathrm{~Hz}) ; 6.27(\mathrm{dd}, 1 \mathrm{H}, \mathrm{J}=2.5 \mathrm{~Hz}, \mathrm{~J}=4.0 \mathrm{~Hz}$ ); $4.80-4.37$ (bs, 4H) ppm; IR (KBr) $v_{\max } 1718,1642,1280,1056 \mathrm{~cm}^{-1} ; \mathrm{MS} \mathrm{m} / \mathrm{z}$ (rel int) $295\left(\mathrm{M}^{+}, 79\right) ; 147$ (6); 132 (100); 131 (72); 105 (33). Anal Calcd for $\mathrm{C}_{16} \mathrm{H}_{13} \mathrm{~N}_{3} \mathrm{OS}: \mathrm{C}, 65.06 ; \mathrm{H}, 4.44 ; \mathrm{N}, 14.23$. Found: $\mathrm{C}, 64.60 ; \mathrm{H}, 4.12$; N, 13.60 .

\section{Reaction of 4 a with carbon disulphide/methyl iodide}

3-Ethoxycarbonyl-2-methylthio-5,6,10b-trihydrothiazolo/3,2-a]pyrrolo[2,1-c]pyrazine (28). To a suspension of the salt $4 \mathrm{a}(0.25 \mathrm{~g}, 0.87 \mathrm{mmol})$ a the biphasic system of $\mathrm{K}_{2} \mathrm{CO}_{3} 50 \%(8 \mathrm{~mL})$ and $\mathrm{CS}_{2}(8 \mathrm{~mL})$, was added Mel $(0.49 \mathrm{~g}, 3.48 \mathrm{mmol})$. After stirring for $20 \mathrm{~h}$ at room temperature, the mixture was extracted with $\mathrm{CH}_{2} \mathrm{Cl}_{2}$, dried over $\mathrm{Na}_{2} \mathrm{SO}_{4}$ and evaporated. Silica gel chromatography in Hex-EtOAc $(9: 1)$ afforded the title compound as a yellow solid (144 mg, 56\%). ${ }^{1} \mathrm{H}-\mathrm{NMR}\left(\mathrm{CDCl}_{3}\right) \delta 6.82(\mathrm{~s}, 1 \mathrm{H}) ; 6.61(\mathrm{~d}, 1 \mathrm{H}, J=1.6 \mathrm{~Hz}) ; 6.16(\mathrm{~d}, 1 \mathrm{H}, J=2.5 \mathrm{~Hz}) ; 6.13-6.11$ $(\mathrm{m}, 1 \mathrm{H}) ; 4.38-4.05(\mathrm{~m}, 4 \mathrm{H}) ; 3.52-3.20(\mathrm{~m}, 2 \mathrm{H}) ; 2.51(\mathrm{~s}, 3 \mathrm{H}) ; 1.34(\mathrm{t}, 3 \mathrm{H}, J=7.1 \mathrm{~Hz}) \mathrm{ppm}$; IR (KBr) $v_{\max } 1682$, $1483,1259,1232,1057 \mathrm{~cm}^{-1}$. Anal Cald for $\mathrm{C}_{13} \mathrm{H}_{16} \mathrm{~N}_{2} \mathrm{O}_{2} \mathrm{~S}_{2}: \mathrm{C}, 52.68 ; \mathrm{H}, 5.44 ; \mathrm{N}, 9.45$. Found: $\mathrm{C}, 52.43 ; \mathrm{H}, 5,39$; $\mathrm{N}, 9.61$.

\section{Reaction of 1 with DMAD}

To a solution of $0.2 \mathrm{~g}$ (1.66 mmol) of 1 in $10 \mathrm{~mL}$ of toluene was added dropwise $0.47 \mathrm{~g}(3.33 \mathrm{mmol})$ of DMAD. After stirring for $3 \mathrm{~h}$, the solvent was evaporated under reduced pressure and the residue was triturated with $\mathrm{Et}_{2} \mathrm{O}$ to give 30 as a brown powder. Recrystallization from $\mathrm{EtOH}$ gave $405 \mathrm{mg}(61 \%) . \mathrm{Mp} 162-163^{\circ} \mathrm{C}(\mathrm{EtOH})$; ${ }^{1} \mathrm{H}-\mathrm{NMR}$ (DMSO-d $\mathrm{d}_{6}$ ) $\delta$ 6.73-6.70 (m, 1H); 6.00-5.97 (m, 2H); 5.58 (dd, $1 \mathrm{H}, \mathrm{J}=1.4 \mathrm{~Hz}, \mathrm{~J}=3.5 \mathrm{~Hz}$ ); 4.11-3.94 (m, $4 \mathrm{H}) ; 3.86(\mathrm{~s}, 3 \mathrm{H}) ; 3.70(\mathrm{~s}, 3 \mathrm{H}) ; 3.67(\mathrm{~s}, 3 \mathrm{H}) ; 3.50(\mathrm{~s}, 3 \mathrm{H}) \mathrm{ppm}$; IR (KBr) $v_{\max } 2953,1723,1613,1435,1204,1125$ $\mathrm{cm}^{-1}$; MS $m / z$ (rel int) $404\left(\mathrm{M}^{+}, 59\right) ; 373$ (100); 345 (58); 315 (16). Anal. Calcd for $\mathrm{C}_{19} \mathrm{H}_{20} \mathrm{~N}_{2} \mathrm{O}_{8}: \mathrm{C}, 56.44 ; \mathrm{H}, 4.99$; $\mathrm{N}, 6.93$; Found: $\mathrm{C}, 56.31 ; \mathrm{H}, 4.90 ; \mathrm{N}, 6.67$.

\section{Synthesis of Salts 32. General Procedure}

A solution of $1(200 \mathrm{mg}, 1.66 \mathrm{mmol})$ and the corresponding iodo derivative (1.66 mmol) in EtOAc $(10 \mathrm{~mL})$ was stirred at room temperature for $24 \mathrm{~h}$. The reaction mixture was cooled and the resulting precipitate was filtered off to give salts 32a-c.

2-(3-Methoxycarbonyl-2-propionyloxycarbonylmethyl)dihydropyrrolo[1,2-a]pyrazinium Iodide (32a). 
Yield: $64 \%$. Mp 119-120 $\mathrm{C}$ (brown powder, EtOH-Et $2 \mathrm{O}$ ); ${ }^{1} \mathrm{H}-\mathrm{NMR}$ (DMSO-d ${ }_{6}$ ) $\delta 8.85(\mathrm{~s}, 1 \mathrm{H}) ; 7.82$ (s, $1 \mathrm{H}$ ); $7.47(\mathrm{~d}, 1 \mathrm{H}, J=4.1 \mathrm{~Hz}) ; 6.89(\mathrm{~s}, 1 \mathrm{H}) ; 6.63(\mathrm{~s}, 2 \mathrm{H}) ; 5.11(\mathrm{~s}, 2 \mathrm{H}) ; 4.44(\mathrm{t}, 2 \mathrm{H}, J=6.4 \mathrm{~Hz}) ; 4.12(\mathrm{t}, 2 \mathrm{H}, J=6.4 \mathrm{~Hz}$ ); $3.69(\mathrm{~s}, 3 \mathrm{H}) \mathrm{ppm}$; IR (KBr) $v_{\max } 2944,2240,1755,1725,1626,1342,1180,1126 \mathrm{~cm}^{-1}$. Anal Calcd for $\mathrm{C}_{14}$ $\mathrm{H}_{15} \mathrm{I} \mathrm{N}_{2} \mathrm{O}_{4}$ : C, 41.81; H, 3.76; N, 6.97. Found: C, 42.01; H, 3.46; N, 7.13.

2-(4-Methoxycarbonyl-3-butymyloxycarbonylmethyl)dihydropyrrolo[1,2-a]pyrazinium lodide (32b). Yield: 69\%. Mp 142-143 ${ }^{\circ} \mathrm{C}$ (brown powder, EtOH-Et $2 \mathrm{O}$ ); ${ }^{1} \mathrm{H}-\mathrm{NMR}$ (DMSO-d ${ }_{6}$ ) $\delta 8.82(\mathrm{~s}, 1 \mathrm{H}) ; 7.80(\mathrm{~s}, 1 \mathrm{H}) ; 7.44$ (dd, $1 \mathrm{H}, J=4.4,1.1 \mathrm{~Hz}) ; 6.62(\mathrm{dd}, 1 \mathrm{H}, J=4.4,2.2 \mathrm{~Hz}) ; 4.89(\mathrm{~s}, 2 \mathrm{H}) ; 4.44(\mathrm{t}, 2 \mathrm{H}, J=6.4 \mathrm{~Hz}) ; 4.11(\mathrm{t}, 2 \mathrm{H}, J=6.4 \mathrm{H}$ z); $3.68(\mathrm{~s}, 3 \mathrm{H}) ; 2.85(\mathrm{t}, 2 \mathrm{H}, J=6.0 \mathrm{~Hz}) \mathrm{ppm}$; IR (KBr) $v_{\max } 2906,2245,1756,1712,1633,1343,1271$, 1201, 1179, $774 \mathrm{~cm}^{-1}$. Anal Calcd for $\mathrm{C}_{15} \mathrm{H}_{17} \mathrm{IN}_{2} \mathrm{O}_{4}: \mathrm{C}, 43.29 ; \mathrm{H}, 4.12 ; \mathrm{N}, 6.73$. Found: $\mathrm{C}, 43.15 ; \mathrm{H}, 4.00$; $\mathrm{N}, 6.48$.

2-(2-Propionyloxycarbonylmethyl)dihydropyrrolol1,2-alpyrazinium lodide (32c). Yield: $81 \%$. Mp 157 $158^{\circ} \mathrm{C}$ (yellow powder from EtOH-Et $\left.{ }_{2} \mathrm{O}\right) ;{ }^{1} \mathrm{H}-\mathrm{NMR}\left(\mathrm{DMSO}_{6} \mathrm{~d}_{6}\right) \delta 8.83(\mathrm{~s}, 1 \mathrm{H}) ; 7.82(\mathrm{~s}, 1 \mathrm{H}) ; 7.46(\mathrm{~d}, 1 \mathrm{H}, J=4.1$ $\mathrm{Hz}) ; 6.89(\mathrm{~s}, \mathrm{lH}) ; 6.64-6.60(\mathrm{~m}, \mathrm{lH}) ; 4.94(\mathrm{~s}, \mathrm{lH}) ; 4.86(\mathrm{~d}, 2 \mathrm{H}, J=2.2 \mathrm{~Hz}) ; 4.44(\mathrm{t}, 2 \mathrm{H}, J=6.4 \mathrm{~Hz}), 4.10(\mathrm{t}, 2 \mathrm{H}$, $J=6.4 \mathrm{~Hz}) ; 3.69(\mathrm{~d}, 1 \mathrm{H}, J=2.2 \mathrm{~Hz}) \mathrm{ppm} ; \mathrm{IR}(\mathrm{KBr}) v_{\max } 3210,2123,1755,1628,1373,1352,1197,1137$ $\mathrm{cm}^{-1}$. Anal. Calcd for $\mathrm{C}_{12} \mathrm{H}_{13} \mathrm{IN}_{2} \mathrm{O}_{2}: \mathrm{C}, 41.88 ; \mathrm{H}, 3.81 ; \mathrm{N}, 8.14$. Found: $\mathrm{C}, 42.11 ; \mathrm{H}, 3.75 ; \mathrm{N}, 8.01$.

2-[2-(2-Methoxycarbonylvinyl)-phenoxycarbonylmethyl]dihydropyrrolo[1,2-a]pyrazinium Iodide (33). Yield: 49\%. Mp 127-128 ${ }^{\circ} \mathrm{C}$ (brown powder, EtOH-Et $\left.2 \mathrm{O}\right) ;{ }^{1} \mathrm{H}-\mathrm{NMR}\left(\mathrm{DMSO}-\mathrm{d}_{6}\right) \delta 8.82(\mathrm{~s}, 1 \mathrm{H}) ; 7.85(\mathrm{~d}, 1 \mathrm{H}, J=$ $16.1 \mathrm{~Hz}$ ); 7.82-7.74 (m, 2H); $7.69(\mathrm{~s}, 1 \mathrm{H}) ; 7.46-7.35(\mathrm{~m}, 2 \mathrm{H}) ; 7.31(\mathrm{dd}, 1 \mathrm{H}, J=4.0,1.1 \mathrm{~Hz}) ; 6.79$ (dd, $1 \mathrm{H}$, $J=4.0,2.1 \mathrm{~Hz}) ; 6.59(\mathrm{~d}, 1 \mathrm{H}, J=16.1 \mathrm{~Hz}) ; 5.54(\mathrm{~s}, 2 \mathrm{H}) ; 4.36(\mathrm{t}, 2 \mathrm{H}, J=6.6 \mathrm{~Hz}) ; 3.95(\mathrm{t}, 2 \mathrm{H}, J=6.6 \mathrm{~Hz}) ; 3.73(\mathrm{~s}$, $3 \mathrm{H}) \mathrm{ppm}$; IR (KBr) $v_{\max } 2948,1743,1707,1628,1456,1433,1324,1279,1172,1127,760 \mathrm{~cm}^{-1}$; Anal Calcd for $\mathrm{C}_{19} \mathrm{H}_{19} \mathrm{IN}_{2} \mathrm{O}_{4}: \mathrm{C}, 48.94 ; \mathrm{H}, 4.11 ; \mathrm{N}, 6.01$. Found: $\mathrm{C}, 49.04 ; \mathrm{H}, 3.82 ; \mathrm{N}, 6.22$.

\section{Intramolecular Cycloadditions}

1-Methoxycarbonyl-4oxo-2,6,7-trihydrofuran/4', 3':4, 5Jpyrrolo/1,2-alpyrrolo/2,1-c/pyrazine (35a). A solution of the salt $32 \mathrm{a}(0.5 \mathrm{~g}, 1.25 \mathrm{mmol})$ and $\mathrm{K}_{2} \mathrm{CO}_{3}(0.18 \mathrm{~g}, 1.25 \mathrm{mmol})$ in dry $\mathrm{MeCN}(12 \mathrm{~mL})$ was stirred at room temperature for $24 \mathrm{~h}$. The reaction mixture was filtered and the solvent was removed under reduced pressure to give a residue which was chromatographed (hexane-EtOAc, 8:2) to yield $35 \mathrm{a}(80 \mathrm{mg}, 24 \%$ ). Mp $174-175^{\circ} \mathrm{C}$ (white powder, EtOAc); ${ }^{1} \mathrm{H}-\mathrm{NMR}\left(\mathrm{CDCl}_{3}\right) \delta 7.55(\mathrm{dd}, 1 \mathrm{H}, J=3.6,1.5 \mathrm{~Hz}) ; 6.83(\mathrm{dd}, 1 \mathrm{H}, J=2.5,1.5$ $\mathrm{Hz}) ; 6.33(\mathrm{dd}, 1 \mathrm{H}, J=3.6,2.5 \mathrm{~Hz}) ; 5.26(\mathrm{~s}, 2 \mathrm{H}) ; 4.44(\mathrm{t}, 2 \mathrm{H}, J=6.0 \mathrm{~Hz}) ; 4.33(\mathrm{t}, 2 \mathrm{H}, J=6.0 \mathrm{~Hz}) ; 3.85(\mathrm{~s}, 3 \mathrm{H}) ; 3.70$ (s, 2H) ppm; IR (KBr) $v_{\max } 2925,2857,1748,1439,1360,1276,1096,1029,740 \mathrm{~cm}^{-1}$; MS m/z (rel int) 272 $\left(\mathrm{M}^{+}, 15\right) ; 271(100) ; 270(13) ; 255(1) ; 239$ (2). Anal. Calcd for $\mathrm{C}_{14} \mathrm{H}_{12} \mathrm{~N}_{2} \mathrm{O}_{4}: \mathrm{C}, 61.76 ; \mathrm{H}, 4.44 ; \mathrm{N}, 10.29$. Found: C, 61.63; H, 4.21; N, 10.46 .

I-Methoxycarbonyl-5-oxo-2,3,7,8-tetrahydropyran [4',3':4,5]pyrrolo/1,2-alpyrrolo[2,1-c]pyrazine (35b). A solution of $32 \mathrm{~b}(0.8 \mathrm{~g}, 1.93 \mathrm{mmol})$ and $\mathrm{K}_{2} \mathrm{CO}_{3}(0.28 \mathrm{~g}, 1.93 \mathrm{mmol})$ in dry $\mathrm{MeCN}(18 \mathrm{~mL})$ was stirred at room temperature for $24 \mathrm{~h}$. The reaction mixture was filtered and the filtrate was concentrated. The residue was chromatographed on silica gel (hexane-EtOAc, 9:1) to give the title compound (165 mg, 30\%). Mp 163-164 ${ }^{\circ} \mathrm{C}$ (white needles, EtOAc); ${ }^{1} \mathrm{H}-\mathrm{NMR}\left(\mathrm{CDCl}_{3}\right) \delta 7.45(\mathrm{dd}, 1 \mathrm{H}, J=3.6,1.6 \mathrm{~Hz}) ; 6.80(\mathrm{dd}, 1 \mathrm{H}, J=2.6,1.6 \mathrm{~Hz}) ; 6.30$ (dd, $1 \mathrm{H}, J=3.6,2.6 \mathrm{~Hz}) ; 4.76(\mathrm{t}, 2 \mathrm{H}, J=6.0 \mathrm{~Hz}) ; 4.52(\mathrm{t}, 2 \mathrm{H}, J=6.2 \mathrm{~Hz}) ; 4.25(\mathrm{t}, 2 \mathrm{H}, J=6.0 \mathrm{~Hz}) ; 3.87(\mathrm{~s}, 3 \mathrm{H}) ; 3.19$ $\left(\mathrm{t}, 2 \mathrm{H}, J=6.2 \mathrm{~Hz}\right.$ ) ppm; IR (neat) $v_{\max } 1698,1440,1312,1272,1214,1131,1092,1078,716 \mathrm{~cm}^{-1}$; MS, $\mathrm{m} / \mathrm{z}$ (rel int) 286 (M+1 100$) ; 255$ (17); 253 (15); 227 (25); $211(15) ; 210$ (16); 169 (12); 142 (12); 128 (12); 115 (13). Anal. Calcd for $\mathrm{C}_{15} \mathrm{H}_{14} \mathrm{~N}_{2} \mathrm{O}_{4}$ : C, 63.93; H, 4.93; N, 9.78. Found: $\mathrm{C}, 64.23 ; \mathrm{H}, 4.79 ; \mathrm{N}, 9.86$. 
Acknowledgment. The authors acknowledge support for this work from the Comisió Interdepartamental de Reçerca i Innovació Técnologica (CIRIT) through the proJect QFN94-4619 and a grant from the Ministerio de Educación y Ciencia (J.M.M.). We thank Profs. R. Carbó and M. Durán and the Centro de Computación de Galixia (CESGA) for providing the computing facilities.

\section{REFERENCES}

1. For a review of azaindolizines see: (a) Amarnath, V.; Madhav, R. Synthesis, 1974, 837-859. (b) Kuhla, D. E.; Lombardino, J. G. Adv. Heterocyclic Chem., 1977, 21, 1-63. (c) Blewit, H. L. Chem. Heterocyclic Comp. 1977, 30, 117-178. (d) Maury, G. Chem. Heterocyclic Comp. 1977, 30, 179-244.

2. Skoldinov, A.; Peresada, B.; Likhosherstov, A. Zh. Org. Khim. 1983, 19, 450-456; Chem. Abstr. 1983, 98, $198162 \mathrm{u}$.

3. Pablo, M. S.; Gandásegui, T.; Vaquero, J. J.; Garcia Navio, J. L.; Alvarez-Builla, J. Tetrahedron, 1992, 48, 8793-8800.

4. a) Hehre, W. J.; Ditchfield, R.; Pople, J. A.; J. Chem. Phys. 1972, 56, 2257-2261. b) Frisch, M. J.;Pople, J. A.; Binkley, J. S.; J. Chem. Phys. 1984, 80, 3265-3269. c) Clark, T.; Chandrasekhar, J.; Spitznagel, G. W; Schleyer, P. V. R. J. Comp. Chem. 1983, 4, 294-301.

5. Goussian 94, Revision B.3, Frisch, M. J.; Trucks, G. W.; Schlegel, H. B.; Gill, P. M. W.; Johnson, B. G.; Robb, M. A.; Cheeseman, J. R.; Keith, T. ; Petersson, G. A.; Montgomery, J. A ; Raghavachari, K.; AlLaham, M. A.; Zakrzewski, V. G.; Ortiz, J. V.; Foresman, J. B.; Peng, C. Y.; Ayala, P. Y.; Chen, W.; Wong, M. W.; Andres, J. L.; Replogle, E. S.; Gomperts, R.; Martin, R. L.; Fox, D. J.; Binkley, J. S.; Defrees, D. J.; Baker, J; Stewart, J. P.; Head-Gordon, M.; Gonzalez, C.; Pople, J. A. Gaussian, Inc., Pittsburgh PA, 1995.

6. These magnitudes are defined respectively as the standard Gibbs energy and enthalpy charges for the following reaction in the gase phase: $\mathrm{BH}^{+}(\mathrm{g}) \rightarrow \mathrm{B}(\mathrm{g})+\mathrm{H}^{+}(\mathrm{g})$

7. Tamura, Y.; Minamikawa, J,; Ikeda, M. Synthesis, 1977, 1-17.

8. Bátori, S.; HaJós, G.; Sándor, P.; Messmer, A. J. Org. Chem. 1989, 54, 3062-3068.

9. Cuadro, A.; Alvarez-Builla, J.; Vaquero, J. J. Heterocycles, 1989, 29, 57-65.

10. Minguez, J. M.; Castellote, M. I.; Vaquero, J. J.; Garcia-Navio, J. L.; Alvarez-Builla, J.; Castaño, O.; Andrés, J. L. J. Org. Chem. 1996, 61, 4655-4665.

11. a) Cuadro, A. M; Novella, J. L.; Molina, A.; Alvarez-Builla, J.; Vaquero, J. J. Tetrahedron, 1990, 46, 60336046. b) Molina, A.; Cuadro, A. M.; Alvarez-Builla, J.; Vaquero, J. J.; Garcia Navio, J. L. Heterocycles, 1990, 3l, 1451-1458. c) Minguez, J. M.; Gandasegui, T.; Vaquero, J. J.; Alvarez-Builla, J. L.; Garcia Navio, J. L.; Grgo, F.; Ortiz, A. R.; Gomez-Sal, P.; Torres, R.; Rodrigo, M. M. J. Org. Chem. 1993, 58, 6030-6037.

12. Zhang, X.-M.; Bordwel, F.; Van Der Puy, M.; Fried, H. E. J. Org. Chem. 1993, 58, 3060-3066.

13. Cuadro, A. M.; Alvarez-Builla, J.; Vaquero, J. J. Heterocycles, 1988, 27, 1233-1240.

14. Munt, P. S.; Thomas, E. J. J. Chem. Soc. Chem. Commun. 1989, 480-482.

(Received in UK 2 April 1997; revised 19 May 1997; accepted 22 May 1997) 